\title{
Title: Prevalence of drug use during sex amongst MSM in Europe: results from a multi-site bio-behavioural survey.
}

Authors:

Magdalena Rosińska ${ }^{\mathrm{a}}$, Lorenzo Gios ${ }^{\mathrm{b}}$, Christiana Nöstlinger ${ }^{\mathrm{c}, 1}$, Wim Vanden Berghe ${ }^{\mathrm{d},}$

${ }^{2}$, Ulrich Marcus ${ }^{\mathrm{e}}$, Susanne Schink $k^{\mathrm{f}}$, Nigel Sherriff ${ }^{\mathrm{g}}$, Anna-Marie Jones ${ }^{\mathrm{h}, 3}$, Cinta

Folch $^{\mathrm{i}}$, Sonia Dias ${ }^{\mathrm{j}}$, Inga Velickok ${ }^{\mathrm{k}}$, Massimo Mirandola ${ }^{1,4}$, Sialon II Network ${ }^{\mathrm{m}}$

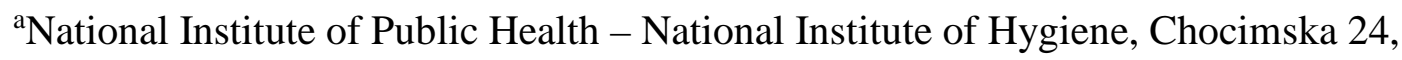

00-791 Warsaw, Poland; Email: mrosinska@pzh.gov.pl

${ }^{b}$ Regional Coordination Centre for European Project Management, Verona University

Hospital, Verona, Veneto Region, Italy; Full Postal Address: CREMPE Regional

Coordination Centre for European Project Management, Verona University Hospital,

Verona, Veneto Region, Italy, p.le Aristide Stefani 1 - 37126 Verona (VR) - Italy;

Email: lorenzo.gios@aovr.veneto.it

${ }^{\mathrm{c}}$ Institute of Tropical Medicine, Department of Public Health Nationalestraat 155,

2000 Antwerp, Belgium; Email: cnoestlinger@itg.be

${ }^{\mathrm{d}}$ Institute of Tropical Medicine, Department of Public Health (Antwerp, Belgium);

Email:wim.vandenberghe@wiv-isp.be

\footnotetext{
${ }^{1}$ University of Vienna, Faculty of Psychologye Liebiggasse 5, 1010 Vienna, Austria

${ }^{2}$ Department of Epidemiology of Infectious Diseases, Scientific Institute of Public Health, Brussels, Belgium

${ }^{3}$ Mill View hospital, Sussex Education Centre, Research \& Development; Brighton, UK

${ }^{4}$ Regional Coordination Centre for European Project Management, Verona University Hospital, Verona, Veneto Region, Italy; Full Postal Address: CREMPE Regional Coordination Centre for European Project Management, Verona University Hospital, Verona, Veneto Region, Italy, p.le Aristide Stefani 1 - 37126 Verona (VR) - Italy
} 
e Robert Koch Institute, Seestr. 10, 13353 Berlin, Germany; Email: MarcusU@rki.de

${ }^{\mathrm{f}}$ Robert Koch Institute, Seestr. 10, 13353 Berlin, Germany; Email: $\underline{\text { SchinkS@rki.de }}$

g School of Health Sciences, University of Brighton, Brighton, BN1 9PH, UK,

Email:n.s.sherriff@brighton.ac.uk

h School of Health Sciences, University of Brighton, Brighton, BN1 9PH, UK;

Email:‥Jones4@brighton.ac.uk

${ }^{\text {i } C e n t r e ~ d ’ E s t u d i s ~ E p i d e m i o l o ̀ g i c s ~ s o b r e ~ l e s ~ I n f e c c i o n s ~ d e ~ T r a n s m i s s i o ́ ~ S e x u a l ~ i ~ S i d a ~}$

de Catalunya (CEEISCAT), Departament de Salut, Generalitat de Catalunya. Hospital

Universitari Germans Trias i Pujol. Ctra de Canyet s/n, 08916 Badalona, Spain;

Email: cfolch@iconcologia.net

${ }^{j}$ Global Health and Tropical Medicine, GHTM, Instituto de Higiene e Medicina

Tropical, IHMT, Universidade Nova de Lisboa, UNL, Portugal; Email:

sfdias@ihmt.unl.pt

${ }^{\mathrm{k}}$ Public Health Agency of Sweden, Stockholm, Sweden; Email:

inga.velicko@folkhalsomyndigheten.se

${ }^{1}$ Infectious Diseases Section, Department of Diagnostics and Public Health,

University of Verona, Verona, Italy; Email: massimo.mirandola@univr.it

m The list of Sialon II Network members is included as Annex 1

Corresponding Author:

Magdalena Rosińska, National Institute of Public Health - National Institute of

Hygiene, Chocimska 24, 00-791 Warsaw, Poland; Email: mrosinska@pzh.gov.pl 


\title{
Title: Prevalence of drug use during sex amongst MSM in Europe: results from a multi-site bio-behavioural survey.
}

\author{
Abstract \\ Background \\ Substance use has been consistently reported to be more prevalent amongst Men who \\ have Sex with Men (MSM) compared to the general population. Substance use, in \\ particular polydrug use, has been found to be influenced by social and contextual \\ factors and to increase the risk of unprotected intercourse among MSM. The objective \\ of this analysis was to investigate the prevalence and predictors of drug use during a \\ sexual encounter and to identify specific prevention needs.
}

\section{Methods/Design}

A multi-site bio-behavioural cross-sectional survey was implemented in 13 European cities, targeting MSM and using Time-Location Sampling and Respondent-Driven Sampling methods. Multivariable multi-level logistic random-intercept model (random effect of study site) was estimated to identify factors associated with the use of alcohol, cannabis, party drugs, sexual performance enhancement drugs and chemsex drugs.

\section{Results}

Overall, 1,261 (30.0\%) participants reported drug use, and 436 of 3,706 (11.8\%) reported the use of two or more drugs during their last sexual encounter. By drug class, 966 (23.0\%) reported using sexual performance enhancement drugs, 353 (8.4\%) - party drugs, and 142 (3.4\%) the use of chemsex drugs. Respondents who reported drug use were more frequently diagnosed with HIV (10.5\% vs. 3.9\%) before and with other STIs during the 12 months prior to the study (16.7\% vs. 9.2\%). The use of all 
the analysed substances was significantly associated with sexual encounter with more than one partner.

\section{Discussion}

Substance and polydrug use during sexual encounters occurred amongst sampled MSM across Europe although varying greatly between study sites. Different local social norms within MSM communities may be important contextual drivers of drug use, highlighting the need for innovative and multi-faceted prevention measures to reduce HIV/STI risk in the context of drug use.

\section{KEYWORDS}

MSM; drug use; recreational drug use; Time-Location Sampling; Respondent-Driven Sampling; Europe

\section{Funding source:}

This paper is based on data from the Sialon II project, funded under the European Commission’s (EC) Public Health Programme 2008-2013 (Work Plan 2010). The sole responsibility lies with the authors of this document/paper and the Commission is not responsible for any use that may be made of the information contained therein 


\section{Background}

Substance use has been consistently reported to be more prevalent amongst men who have sex with men (MSM) populations compared to the general population (Hunter, Dargan, Benzie, White, \& Wood, 2014; Mercer et al., 2016; Mor \& Davidovich, 2016; Wohl, Frye, \& Johnson, 2008). Studies have addressed legal substances such as alcohol or tobacco as well as diverse illegal substances and medications used without prescription, the use of the last two refered to as drug use.

The available literature suggests that patterns of drug use among MSM differ from men who report sex with women only (Feaster et al., 2016; Hunter et al., 2014; Lhomond, Saurel-Cubizolles, Michaels, \& CSF Group, 2014; Wohl et al., 2008). Moreover, the evidence also suggests that particular MSM populations may also be more likely to use drugs associated with visiting clubs or venues (e.g. cocaine, ecstasy, $\gamma$-hydroxybutyrate - GHB/ $\gamma$-butyrolactone - GBL, hallucinogens, methamphetamines)(Feaster et al., 2016; Wohl et al., 2008) and less likely to inject opiates (Feaster et al., 2016).

Substance use amongst MSM has also been shown to be associated with societal contextual factors like stigma, poverty, trauma, and, at individual level, internalised homophobia, resulting from negative attitudes towards homosexuality in the environment (Edelman et al., 2016; Wilson et al., 2016). Perceived stigma towards gay/bisexual individuals has also been found to be an important predictor of reduced service use, for example reduced HIV testing uptake, of increased risk behaviours and poorer mental health (Martinez et al., 2016; Pachankis, Hatzenbuehler, Mirandola, et al., 2017; Vanden Berghe, Nöstlinger, \& Laga, 2014). The co-occurrence of these negative health outcomes can be framed within the emergent approach of syndemics, consisting of interacting diseases and the social and environmental factors that 
promote their negative effects on individuals and populations (Singer, Bulled, Ostrach, \& Mendenhall, 2017). Syndemics of substance use, depression, and violence have been identified amongst MSM (Jie, Ciyong, Xueqing, Hui, \& Lingyao, 2012; Stall et al., 2003; Vanden Berghe et al., 2014) and could be explained within the framework of the minority stress model (Meyer, 2003).

Recent trends in drug use amongst MSM show evolving use patterns specifically associated with sex. In this context, several stimulants termed 'chemsex' drugs (typically mephedrone, GHB/ GBL, and crystallised methamphetamine) appear to be increasingly used (Kirby \& Thornber-Dunwell, 2013). Chemsex drugs are usually taken to prolong sexual pleasure and activity, increase sexual self-confidence as well as enhance the perceived quality of sex (Weatherburn, Hickson, Reid, Torres-Rueda, \& Bourne, 2017). Social and cultural norms in gay subcultures and the party context festive scenes may play an important role in explaining the increasing popularity of chemsex. For example, they may be related to the supposed ubiquity of chemsex or to what it is permitted by or expected from engaging in chemsex (Ahmed et al., 2016).

Substance use amongst MSM, and specifically drug use is a key public health concern because it is often associated with sex in specific contexts and may thus be linked to the transmission of HIV and other sexually transmitted infections (STIs) (Carey et al., 2009; Daskalopoulou et al., 2014). Substance use, in particular polydrug use, has been found to increase the risk of unprotected anal intercourse or sero-discordant unprotected anal intercourse (Daskalopoulou et al., 2014; Santos et al., 2013; Tieu et al., 2014). However, there may be differences between the impact of particular 
substances on risk taking and HIV/STI risk (Carey et al., 2009; Vosburgh, Mansergh, Sullivan, \& Purcell, 2012).

In Europe, the use of psychoactive substances among MSM in association with sex appears to be present consistently, although with different prevalence and patterns across the region (Schmidt et al., 2016). Whilst substance use has been described amongst MSM for some countries, the patterns of use are poorly understood in other countries, in particular in Central- Eastern and Southern Europe. Understanding this phenomenon is important in order to improve individual sexual health (e.g. through counselling) and to strengthen prevention services for STIs including HIV. This is even more so, in view of increasing mobility of MSM in Europe and worldwide and risk behaviours, including drug use, undertaken when travelling (Lee, Sullivan, \& Baral, 2017; Vanden Berghe, Nöstlinger, Hospers, \& Laga, 2013).

The objective of this analysis was to investigate the prevalence and predictors of drug use during a sexual encounter amongst MSM. Our focus is on the event-based analysis, including sexual partner characteristics and drug use during the same sexual encounter. We aim at characterising sexualised drug use in a large community sample of MSM who participated in the Sialon II study in 13 cities across Europe, both Western and Eastern, in view of specific prevention needs. 


\section{Methods}

\section{Study design and enrolment}

This multi-site bio-behavioural cross-sectional survey was implemented in 13 European cities: Brussels (Belgium), Sofia (Bulgaria), Hamburg (Germany), Verona (Italy), Vilnius (Lithuania), Warsaw (Poland), Lisbon (Portugal), Bucharest (Romania), Bratislava (Slovakia), Ljubljana (Slovenia), Barcelona (Spain), Stockholm (Sweden), and Brighton (UK). A detailed description of the study methodology has been published elsewhere (Gios et al., 2016).

Male individuals were enrolled in the study cities during the data collection period in line with the following inclusion criteria: having had sex (any kind of sex) with another man during the previous 12 months, having provided informed consent, and agreed to donate a biological sample (oral fluid or blood depending on the enrolment approach adopted in the given city). Anonymous data collection took place from April 2013 to November 2014.

Two different data collection methods were used to identify and recruit MSM based on formative research conducted in each study site. Time-Location (or time-space) sampling (TLS) was used in nine cities (i.e. Brussels, Sofia, Hamburg, Warsaw, Lisbon, Ljubljana, Barcelona, Stockholm, and Brighton), whilst Respondent Driven Sampling (RDS) was adopted in four cities (Bratislava, Bucharest, Verona, and Vilnius).

In each city, the survey was implemented through trained community field workers using the same methodology (adopting study protocols, laboratory algorithms, and questionnaires). A target number of 400 MSM per city was planned with an expected total of $n=5,200$ participants for the entire survey. Due to difficulties with RDS recruitment in Bucharest, the intended sample size was not reached in Bucharest. 


\section{Study population}

Overall, a total of 4,901 MSM were surveyed: 3,596 MSM through TLS and 1,305 through RDS. An extensive description of the study sample characteristics is available in the Sialon II bio-behavioural survey report (The Sialon II Project, 2016).

For the purpose of this analysis, we included only those MSM who reported having had anal intercourse with another man during the last six months $(\mathrm{N}=4,266)$. Another words we analysed only the anal sex events reported for a well-defined time period (October 2012 - November 2014).

\section{Instruments}

Questionnaire

A structured pen-and-paper questionnaire was used to collect self-reported behavioural information. The draft questionnaire was translated into the languages of the participating countries and piloted before survey implementation. Translations were back-translated into English to check consistency.

\section{Laboratory testing of biological samples}

The TLS protocols stipulated that oral fluid (OF) samples were collected and tested for HIV antibodies using Genscreen ${ }^{\mathrm{TM}}$ HIV 1/2 version 2, BIO-RAD. A total IgG antibodies ELISA test Human IgG ELISA Kit 1x96, Quantitative / Immunology Consultants Laboratory was used for OF sample testing suitability and quality control. All HIV-reactive samples were re-tested with Vironostika HIV Ag/Ab, BioMérieux. Samples tested positive to the first ELISA HIV test, but negative to the second were classified as negative. Study participants could use their unique personal identifier to 
receive their test results if they wished. Referral for diagnostic testing and further case management was established in line with local procedures.

The RDS survey included pre/post-test counselling in the enrolment and follow-up process. Blood samples were collected and serum extracted in line with the local standard procedures. Serum samples were tested with a HIV $4^{\text {th }}$ generation ELISA/CLIA screening test. A Western Blot test was used to confirm positive cases. In case of confirmed HIV positive result, a referral procedure was put in place in line with the local standard procedures to ensure proper case management.

\section{Ethics}

Local Ethics Committees approved the study protocols at each study site. The WHO Research Project Review Panel (RP2) and successively the WHO Research Ethics Review Committee (ERC) approved the protocol prior to data collection.

\section{Variables definition}

\section{Dependent variables}

Self-reported substance use during last anal intercourse with a male partner was assessed using the following question: "Before or during your last anal sexual intercourse, did you use the following...?” The substances listed included: alcohol, poppers, ecstasy, erectile dysfunction medications - Sildenafil/Tadalafil (asked by brand names Viagra ${ }^{\circledR} /$ Kamagra/Cialis $\left.{ }^{\circledR}\right)$, hashish/marijuana, cocaine, amphetamine, and GHB//GBL/ketamine. Participants were also asked to provide names of other substances which they had used. Possible answers were “yes”, “no”, "prefer not to answer”. Missing answers were imputed with "no" and "prefer not to answer" was set 
to missing, as some participants tended to use this question as a check-box question marking only the "yes” answers. The percent of missing answers by substance varied between $17.1 \%$ and $18.5 \%$ with an exception of the two most commonly reported substances: alcohol (8.2\%) and poppers (14.3\%).

Additionally, summary variables were also created: 1 ) use of party drugs during the last anal sex with a male partner defined as the use of any of MDMA, cocaine or amphetamine; 2) use of sexual performance enhancement drugs defined as the use of either poppers or erectile dysfunction medication (EDM); 3) use of chemsex drugs defined as the use of any of GHB/GBL, ketamine, mephedrone or crystal methamphetamine (the last two recoded from the open text question).

\section{Independent variables}

The following independent variables were considered for the analysis: age (calculated using the self-reported year of birth), migration status (native: born \& live in the study country; emigrant: born in the study country \& live abroad; immigrant: born abroad \& live in the study country; visitor: born \& live abroad) - recoded in multivariable analysis to mobile (emigrant, visitor or immigrant) or native, educational status (up to and including secondary school, high school or post-secondary education or university/higher), outness (being out about one’s own sexual orientation to majority of one's social network or to less than half of the network members), perceived attitudes of parents, at work/school and of friends/ acquaintances towards MSM, bisexuality (based on self-reported sexual behaviour in the last six months), selfreported HIV status, diagnosis of a sexually transmitted infection other than HIV (STI) in the past 12 months, having ever injected a drug (lifetime), type of partner/partners during the sexual event for which the drug use was recorded (i.e. with 
a steady partner, with a non-steady partner, with more than one partner), frequenting gay venues (the number of times the participant attended any gay venues such as social venues, bars, discos, clubs, porn cinemas, cruising areas during past three months; recoded for analysis into two categories with the cutting point at median value), sexual satisfaction (Likert scale from very satisfied to very unsatisfied recorded to very satisfied versus not very satisfied - including all other categories for the analysis).

\section{Data analysis}

The prevalence of use of a substance was defined as the proportion of MSM who reported using the substance during the last sexual encounter associated with anal sex with another men, among MSM who reported having had an anal intercourse with another man within 6 months preceding participation in the study.

Descriptive statistics, Wilcoxon-Mann-Whitney test, and Kruskal-Wallis test by ranks were used for quantitative variables, whilst percentages and Fisher's exact test were used for nominal variables.

Multivariable multi-level logistic random-intercept model (random effect of study site) was estimated to account for the hierarchical structure of the data (Rabe-Hesketh, Skrondal, \& Skrondal, 2008). The multi-level analysis was conducted to identify factors associated with the use of alcohol, cannabis, party drugs, sexual performance enhancement drugs and chemsex drugs. Predictors associated with the outcome variable with a probability $<0.05$ were considered significant and backwards selection was used to identify the most relevant co-variates. Cases with missing values in the studied predictors were excluded from the analysis.

Stata® Version 14.2 was used for all analyses (College Station, TX: StataCorp LP). 


\section{Results}

Study group characteristics

In total 4,266 individuals were included in the study. Participants’ median age was 32 years (interquartile interval 25-40 years), $81.4 \%$ lived in the country they were born in and, where they were recruited and 55\% completed university education (Table 1). A large majority (87.3\%) reported only male sexual partners in the past six months and $12.7 \%$ reported male and female partners.

Among the participants, 4,202 (99.4\%) provided sufficient information on whether they had used any substance at the last anal intercourse with a male partner and 3,706 (86.8\%) - also sufficient to establish the number of substances used. Overall, 1,261 (30.0\%) participants reported drug use, and 436 of 3,706 (11.8\%) reported the use of two or more drugs during their last sexual encounter. By drug class, 966 (23.0\%) reported using sexual performance enhancement drugs, 353 (8.4\%) - party drugs, and 142 (3.4\%) the use of chemsex drugs. Although drug use was prevalent in all age groups, there were differences in age distribution by the class of drug (Fig. 1). Whilst the use of sexual performance enhancement drugs increased with age, the use of party drugs and chemsex drugs was less prevalent in the older age groups.

The proportion of men who attained a university degree was generally lower amongst those who used drugs (50.9\% vs 57.2\%) with an exception of those who used chemsex drugs of whom 67.2\% completed university education (Table 1). The proportion of participants who were 'out' (i.e. being open about their sexual orientation) to the majority of their extended social network was higher in the group who had used drugs during the last anal sex (63.8\%), especially amongst those who used chemsex drugs (84.7\%), than amongst those who did not use drugs (55.5\%). 
Respondents who used drugs more frequently reported to be diagnosed with HIV (10.5\% vs. 3.9\%) (self-reported status) and to have been diagnosed with another STI during the 12 months prior to the study (16.7\% vs. 9.2\%). Similarly, they were more likely to report a history of injecting drugs (7.7\% vs. 2.6\%). On average, participants reported having attended gay venues 18.8 times (median 7) during the past three months, but the average was higher (23.7 times, median 11) in the group who used a drug during the last sexual encounter.

Finally, the distribution of partner type differed according to drug use. In the group who reported the use of any drug and the group who reported the use of chemsex drugs, $12.9 \%$ and $22.3 \%$ respectively also reported more than one partner during the event as opposed to 3.3\% in the group who did not use any drug. Those who used chemsex drugs more often declared to be very satisfied with their sexual lives (44.2\%) than those who had not used drugs (31.9\%) or had used drugs of other classes.

Substance use by study site

Substance use during the last sex differed significantly across the study sites (Table 2). The most frequently used substances were alcohol reported by $45.2 \%$ of participants, ranging from $23.8 \%$ in Verona to $59.6 \%$ in Sofia, and sexual performance enhancement drugs reported by $23.1 \%$, ranging from $6.1 \%$ in Verona to 42.9\% in Brussels. Other substances were used by less than $10 \%$ of the overall sample, but with significant variation across cities. Reported party drug use was the highest in Brussels (21.2\%), Barcelona (15.3\%) and Brighton (13.0\%), and chemsex drug use was the highest in Brussels (13.9\%), Brighton (9.3\%) and Ljubljana (6.0\%). Two most commonly observed patterns of drug use were: 1 ) predominance of poppers use ( $>40 \%$ of those who used any drugs used only poppers) in Bratislava, Hamburg, Sofia, Stockholm, Vilnius and Warsaw; 2) a large proportion of polydrug use ( $>20 \%$ 
of those who used any drug used three or more substances) in addition to $20-30 \%$ using only poppers in Barcelona, Brighton, Brussels, Lisbon and Ljubljana. For Lisbon and Verona higher proportion of cannabis were reported. Bucharest had a high proportion of missing information on substance use (Supplementary Figure 1).

\section{Predictors of substance use}

The univariable analysis of predictors of substance use is presented in the Supplementary Table 1.

a. Alcohol use

In the multivariable analysis of alcohol use the significant predictors with the largest effect sizes were the sexual encounter with more than one partner vs single steady partner (adjusted odds ratio, AOR 2.4, 95\%CI 1.7-3.3) and a history of injecting drugs (2.0, 1.3-2.9). Younger age, lower education, having had both female and male partners vs only male, and frequent visiting of gay venues also predicted alcohol use (Table 3).

b. Cannabis use In turn, cannabis use was associated the most with having both male and female partners (AOR 3.2, 95\%CI 2.2-4.5), being out about sexual orientation to majority of the social network $(2.5,1.8-3.4)$, sexual encounter with more than one partner (2.4, 1.5-3.8) and having injected drugs in the past (2.5, 1.5-4.1). Other important factors, although with smaller effect sizes, included younger age and lower education.

c. Sexual performance enhancement drugs use The odds of use of sexual performance enhancement drugs significantly increased in sexual encounters with more than one partner vs one steady partner (AOR 5.6, 95\% CI 4.0-7.9) and in MSM reporting positive HIV status (2.0, 1.4-2.8). Increased odds 
of using these drugs were also noted for older ages, lower education, having both male and female partners, history of injecting drugs, frequent visiting of gay venues, being satisfied with sexual life and an STI diagnosis in the past 12 months.

d. Party drugs use

The party drug use strongly correlated with history of injecting drugs (AOR 4.8, 95\% CI 3.0-7.6) and sexual encounter with more than one partner (3.5, 2.2-5.7), as well as being out to the majority of social network $(2.0,1.4-2.8)$ and having both male and female partners (2.2, 1.5-3.2). It was also associated with younger age, being mobile (migrant or travelling), negative family attitude towards MSM, frequent attendance at gay venues and an STI diagnosis within the past 12 months.

e. Chemsex drugs use

The use of chemsex drugs was strongly associated with sexual encounter with more than one partner vs one steady partner (AOR 7.4, 95\% CI 3.9-14.0), history of injecting drugs (5.8, 3.0-11.2) and an STI diagnosis in the past 12 months (3.0, 1.8 5.1). Younger age and university education predicted chemsex use as well. 


\section{Discussion}

Our results quantify the frequency of substance use during sexual encounters amongst MSM sampled in study sites across Europe. Alcohol was the most commonly reported substance used by nearly half of the participants. Drug use, most commonly sexual performance enhancement drugs use, was reported in less than a third of anal sex events.

It is important to underline that the data collected for this behaviour referred to the last sexual encounter. Clearly, this estimate is not directly comparable with the proportion of MSM who use drugs in general, be it during sex or in other contexts. Moreover, the proportion of sexual encounters, during which MSM use substances can be interpreted in the context of the frequency of sexual encounters in this group. A study in U.S. established that MSM engaged in an estimated average of 81 sex acts per year (Wall, Stephenson, \& Sullivan, 2013). Thus, although possibly using drugs on two different encounters is correlated it is still very likely that asking about drug use at sex during a three/six-month period would yield a higher estimate of the proportion of MSM, who report this behaviours.

Nevertheless, the relative frequency of using these substances established in our study is consistent with the results of prior studies in Europe and in the US, which collected information on use during the past six months (Feaster et al., 2016; Schmidt et al., 2016). One notable exception is cannabis, which was relatively more common in these studies than in ours. Because our study asked specifically about the use before or during sex, this may indicate that in this study population cannabis is less used in sexual contexts in contrast to other social situations.

Prevalence of drug use, including the different types of drugs used, varied greatly across the study cities. The use of any drug ranged from $12.9 \%$ in Vilnius to $52.9 \%$ in 
Brussels. Although there is a substantial variation between the different study sites as to the particular substances used, we note that poppers as a single substance or in combination with alcohol were the most commonly used substances. Polysubstance use is quite frequent, given that in 4 out of 13 study sites using three or more substances (excluding alcohol) accounted for over $20 \%$ of all sexual encounters associated with substance use. To some extent these differences may be related to the characteristics of the participants recruited in different study locations. However, we note that even in the multivariable models the (random) effect of the city remained significant. This draws attention to different social or sub-cultural norms related to drug use within the studied populations, as observed in a prior study (Chard, Metheny, Sullivan, \& Stephenson, 2017). Moreover, the observed differences may be related to differences in supply, prices and availability of particular substances on the local markets. Data collated by the European Monitoring Centre for Drugs and Drug Addictions (http://www.emcdda.europa.eu/data/stats2017) indicate substantial diversity in terms of drug prices and prevalence of use between various European countries.

The demographic predictors of drug use identified in our models include age and education. In line with our results younger age was previously described as a predictor of drug use, especially chemsex and polysubstance use (Daskalopoulou et al., 2014; Schmidt et al., 2016; Sewell et al., 2017). In addition, we identified older age as predictor of increased use of sexual performance enhancement drugs, which points to differential patterns of drug use by age. University education predicted less alcohol and drug use in our study, with exception of chemsex drugs, which were in fact more prevalent among the university graduates. The prior findings on the role of university education are mixed. Some studies report higher drug use amongst less educated 
MSM (e.g. (Sewell et al., 2017)). In others, university education predicted in e.g. higher prevalence of polysubstance use (Daskalopoulou et al., 2014) or education was not associated to chemsex (Glynn et al., 2018). As indicated also by our results, the effect could differ depending on the particular drugs studied.

In our study MSM who also have sex with women (MSMW) showed increased odds of substance use with the largest effect sizes for cannabis and party drug use. There is prior evidence that this sub-population of MSM can have specific patterns of drug use in general (Lhomond et al., 2014). MSMW not only represent a sub-population of MSM with specific needs, but also with different access to services such as HIV screening, with increased odds of both less recent test seeking behaviour and lifetime HIV testing (Mirandola, Gios, Davis, et al., 2017; Mirandola, Gios, Sherriff, et al., 2017).

Generally, amongst specific MSM subpopulations like MSMW, but also migrant MSM, overlapping or dual stigma plays a key role in providing further insight of risky behavioural patterns (Mirandola, Gios, Davis, et al., 2017; Mirandola, Gios, Sherriff, et al., 2017; Pachankis, Hatzenbuehler, Berg, et al., 2017). In our study, being a migrant predicted party drug use and alcohol use, but the difference with respect to the native population was small.

“Outness” appeared to have an enhancing effect on the use of party drugs, chemsex drugs and cannabis in our study. This is unexpected given that concealment has been shown to increase the odds of sexual risk behaviours and suboptimal service use in a recent study (Pachankis et al., 2015). However, drug use was not specifically investigated in that study and the association of “outness” with increased drug use is in fact supported in other studies (Petersson, Tikkanen, \& Schmidt, 2016). This 
relationship could be mediated through attendance at sex parties. Previous research demonstrated the high prevalence of chemsex use during sex parties in public venues (especially gay venues) and was found to be even higher amongst those attending private sex parties (Schmidt et al., 2016). While we corrected in our model for higher attendance in gay venues, we did not have sufficient information about private party attendance.

Drug use was also associated with the type of sexual partner(s). In fact, sexual encounters were more closely related to drug use when more than one sexual partner was involved. Group sex indicated an almost six-times higher chance of using sexual performance enhancement drugs and increased over seven times the chances of using chemsex drugs. This is in line with previous studies associating drug use with sex parties and with multiple partners during sexual encounter (Ahmed et al., 2016; Ober, Shoptaw, Wang, Gorbach, \& Weiss, 2009). MSM reporting group sex have been found to exhibit higher sexual risk and polysubstance use. They were also more likely to suffer from psychosocial problems, supporting evidence of syndemic effect (Hirshfield et al., 2015).

Perceived negative attitudes towards gay and bisexuals, as measured in different contexts (at work/school, amongst friends, family and parents), did not correlate with the reported drug use, with the only exception of parental/ family negative attitudes increasing the risk of party drug use. These findings do not fully support the general syndemic theory, in line with which the negative social attitudes may result in minority stress, internalized homonegativity and, in consequence, the co-occurrence of mental health problems, including substance use and increased risk taking (Martinez et al., 2016; Pachankis, Hatzenbuehler, Mirandola, et al., 2017; Vanden 
Berghe et al., 2014). However, also the results of the prior research on syndemics related specifically to substance use are mixed. Some studies suggest that drug use among MSM is a strategy to cope with HIV diagnosis, internalised homonegativity, and depression (Edelman et al., 2016). On the other hand it has been also indicated that minority stress may be rather associated with substance dependence and less so with recreational substance use (Lea, de Wit, \& Reynolds, 2014). This last finding corresponds to our results, as we studied the recreational use, not referring to dependence and/or problem drug use. In addition, other research indicates that recreational drug use may be driven by local social norms (Chard et al., 2017), especially those associated with specific social spaces, clubs or sex-parties (Ahmed et al., 2016; Mereish, Goldbach, Burgess, \& DiBello, 2017). We found that being 'out' and frequently attending gay venues increased chances of alcohol and drug use during the last sexual encounter, which indirectly supports the importance of these norms. Enhancing sexual experience was identified as one of the motivations for sex-related drug use (Bourne, Reid, Hickson, Torres Rueda, \& Weatherburn, 2014; Weatherburn et al., 2017). In our multivariable models being very satisfied with one’s sexual life was significantly associated with sexual performance enhancement drug use. However, the univariable effect was the strongest for chemsex drugs. It was not significant in the multivariable model, possibly due to smaller number of respondents reporting chemsex drug use.

Finally, even if injecting drugs in the past was only reported by small minority of our respondents (4.4\%), our study confirmed strong correlations between having ever injected a drug and drug use during sex. Injection history was associated with approximately five times higher odds of party drug use and almost six times higher odds of chemsex drugs use. As noted by Glass et al. (Glass, Hope, Tanner, \& Desai, 
2017) injecting drugs associated with sexualised drug use ('slamming') may be on the increase. Although we did not collect information on whether or not injecting took place in the context of sexual encounters, we note that at least the subgroups of MSM who inject drugs and MSM who practice chemsex overlap.

\section{Limitations}

There are possible pitfalls in interpreting the results of our study. Firstly, drug use and other covariates were measured through a self-administered questionnaire, which carries the risk of incorrect or incomplete reporting. While anonymity may have mitigated this effect to a certain extent, we cannot exclude the possibility of recall bias and that participants may have underreported substance use due to social desirability or misinterpretation of the questions. This could be especially true for 'chemsex' drugs as the use of mephedrone and crystal methamphetamine was not asked directly, but established based on an open text field. Adopting a community-based approach in collaboration with trustful community organisations to reach different groups of MSM, potentially contributed to reducing social desirability biases.

A second limitation is related to the sampling methodology. TLS and RDS methods are considered quasi-probabilistic approaches, targeting only those MSM associated with specific MSM communities either through their attendance in gay venues (TLS) or through personal social network (RDS). These approaches are subject to specific drawbacks, including possible over- or under-representation of potential MSM subsamples (Kendall et al., 2008). Additionally, the difficulties with RDS recruitment in Bucharest could have affected the sample representativeness and the estimates' precision in this city. Nonetheless, the adopted methods represent a benchmark in biobehavioural surveys and allow reaching wide representation of the target population. 
Finally, findings of this analysis should not be directly generalised to all European MSM, as it is not possible to exclude the influence of unmeasured common patterns or contextual factors (such as cultural variations, social norms) not taken into account in this study design. Nevertheless, as the study succeeded in recruitment of a large number of participants across diverse settings in Europe, it offers a pan-European perspective.

\section{Conclusions}

We found that drug use before or during sexual encounters occurs among MSM in all studied sites in Europe, although it appears relevant only for a fraction of MSM. While some common predictors were established for all classes of drugs, some important differences found in this study underline the complexity of drug use amongst MSM. The differentiated patterns of drug use between the study sites draw attention to these populations' specific needs and call for innovative and multi-faceted prevention measures to reduce of HIV/STI risk in the context of drug use adapted to local contexts. Although some studies have highlighted the potential role of drug use, particularly 'chemsex', in facilitating the adoption of sexual risk behaviours (e.g. UAI) amongst MSM, by reducing behavioural control when under the influence of drugs (Bourne et al., 2014), the causal relationship is debatable (Digiusto \& Rawstorne, 2013; Edelman et al., 2016; Melendez-Torres \& Bourne, 2016). Referring to syndemics' theory, both risky behaviour and drug use may be related to social environments stigmatising towards gay and bisexual men (Martinez et al., 2016; Santos et al., 2014; Vanden Berghe et al., 2014). 
Consequently, new intervention models underline tailoring the measures to individual profiles, considering possible co-existing conditions, such as depression, potentially mediating drug use and risky behaviours (Achterbergh, van der Helm, van den Brink, \& de Vries, 2017; Fletcher \& Reback, 2015). Taking on a harm-reduction approach and the implementation of outpatient drug use counselling within LGBTI-focused services was shown to be successful in terms of both reduced drug-use and improved psychosocial outcomes (Lea et al., 2017). These could include the STI/HIV community based services, which may attract MSM who do not perceive drug use as their particular problem. Community-based approaches including outreach may also be of value, changing individual behaviour through targeting social and community norms (Lauby et al., 2017). Our main findings confirm that local social norms within MSM communities may be important contextual drivers of drug use among MSM. 


\section{Authors' contributions}

The Sialon II network participated in the design of the survey questionnaire and the organisation and implementation of the survey in the survey cities. All co-authors developed the concept of this manuscript. MR analysed the data. The first draft was jointly written by MR, LG and MM and all authors revised the manuscript for important intellectual content. All authors read and approved the final manuscript.

\section{Acknowledgements}

This manuscript is based on data from the Sialon II project, co-funded under the European Commission’s (EC) Public Health Programme 2008-2013 (Work Plan 2010). The sole responsibility lies with the authors of this manuscript and the Commission is not responsible for any use that may be made of the information contained therein.

\section{Conflict of interests}

The authors declare that they have no conflict of interest.

\section{References}

Achterbergh, R. C. A., van der Helm, J. J., van den Brink, W., \& de Vries, H. J. C. (2017). Design of a syndemic based intervention to facilitate care for men who have sex with men with high risk behaviour: the syn.bas.in randomized controlled trial. BMC Infectious Diseases, 17(1), 398.

https://doi.org/10.1186/s12879-017-2474-x

Ahmed, A.-K., Weatherburn, P., Reid, D., Hickson, F., Torres-Rueda, S., Steinberg, P., \& Bourne, A. (2016). Social norms related to combining drugs and sex 
(“chemsex”) among gay men in South London. The International Journal on Drug Policy, 38, 29-35. https://doi.org/10.1016/j.drugpo.2016.10.007

Bourne, A., Reid, D., Hickson, F., Torres Rueda, S., \& Weatherburn, P. (2014). The Chemsex study: drug use in sexual settings among gay \& bisexual men in Lambeth, Southwark \& Lewisham. London: Sigma Research, London School of Hygiene \& Tropical Medicine. Retrieved from www.sigmaresearch.org.uk/chemsex

Carey, J. W., Mejia, R., Bingham, T., Ciesielski, C., Gelaude, D., Herbst, J. H., ... Stall, R. (2009). Drug use, high-risk sex behaviors, and increased risk for recent HIV infection among men who have sex with men in Chicago and Los Angeles. AIDS and Behavior, 13(6), 1084-1096. https://doi.org/10.1007/s10461-008-9403-3

Chard, A. N., Metheny, N. S., Sullivan, P. S., \& Stephenson, R. (2017). Social Stressors and Intoxicated Sex Among an Online Sample of Men who have Sex with Men (MSM) Drawn from Seven Countries. Substance Use \& Misuse, 19. https://doi.org/10.1080/10826084.2017.1322985

Daskalopoulou, M., Rodger, A., Phillips, A. N., Sherr, L., Speakman, A., Collins, S., ... Lampe, F. C. (2014). Recreational drug use, polydrug use, and sexual behaviour in HIV-diagnosed men who have sex with men in the UK: results from the cross-sectional ASTRA study. The Lancet HIV, 1(1), e22-e31. https://doi.org/10.1016/S2352-3018(14)70001-3

Digiusto, E., \& Rawstorne, P. (2013). Is it really crystal clear that using methamphetamine (or other recreational drugs) causes people to engage in unsafe sex? Sexual Health, 10(2), 133-137. https://doi.org/10.1071/SH12053 
Edelman, E. J., Cole, C. A., Richardson, W., Boshnack, N., Jenkins, H., \& Rosenthal, M. S. (2016). Stigma, substance use and sexual risk behaviors among HIVinfected men who have sex with men: A qualitative study. Preventive Medicine Reports, 3, 296-302. https://doi.org/10.1016/j.pmedr.2016.03.012

Feaster, D. J., Parish, C. L., Gooden, L., Matheson, T., Castellon, P. C., Duan, R., ... Metsch, L. R. (2016). Substance use and STI acquisition: Secondary analysis from the AWARE study. Drug and Alcohol Dependence, 169, 171-179. https://doi.org/10.1016/j.drugalcdep.2016.10.027

Fletcher, J. B., \& Reback, C. J. (2015). Depression mediates and moderates effects of methamphetamine use on sexual risk taking among treatment-seeking gay and bisexual men. Health Psychology: Official Journal of the Division of Health Psychology, American Psychological Association, 34(8), 865-869. https://doi.org/10.1037/hea0000207

Gios, L., Mirandola, M., Toskin, I., Marcus, U., Dudareva-Vizule, S., Sherriff, N., ... Rafila, A. (2016). Bio-behavioural HIV and STI surveillance among men who have sex with men in Europe: the Sialon II protocols. BMC Public Health, 16, 212. https://doi.org/10.1186/s12889-016-2783-9

Glass, R., Hope, V. D., Tanner, C., \& Desai, M. (2017). “Slamming” among men who have sex with men accessing general drug services, in response to Schmidt, AJ et al., 2016, Illicit drug use among gay and bisexual men in 44 cities: Findings from the European MSM Internet Survey (EMIS). International Journal of Drug Policy, 49, 24-25. https://doi.org/10.1016/j.drugpo.2017.07.028

Glynn, R. W., Byrne, N., O’Dea, S., Shanley, A., Codd, M., Keenan, E., ... Clarke, S. (2018). Chemsex, risk behaviours and sexually transmitted infections among 
men who have sex with men in Dublin, Ireland. International Journal of Drug Policy, 52, 9-15. https://doi.org/10.1016/j.drugpo.2017.10.008

Hirshfield, S., Schrimshaw, E. W., Stall, R. D., Margolis, A. D., Downing, M. J., \& Chiasson, M. A. (2015). Drug Use, Sexual Risk, and Syndemic Production Among Men Who Have Sex With Men Who Engage in Group Sexual Encounters. American Journal of Public Health, 105(9), 1849-1858. https://doi.org/10.2105/AJPH.2014.302346

Hunter, L. J., Dargan, P. I., Benzie, A., White, J. A., \& Wood, D. M. (2014). Recreational drug use in men who have sex with men (MSM) attending UK sexual health services is significantly higher than in non-MSM. Postgraduate Medical Journal, 90(1061), 133-138. https://doi.org/10.1136/postgradmedj2012-131428

Jie, W., Ciyong, L., Xueqing, D., Hui, W., \& Lingyao, H. (2012). A Syndemic of Psychosocial Problems Places the MSM (Men Who Have Sex with Men) Population at Greater Risk of HIV Infection. PLoS ONE, 7(3), e32312. https://doi.org/10.1371/journal.pone.0032312

Kendall, C., Kerr, L. R. F. S., Gondim, R. C., Werneck, G. L., Macena, R. H. M., Pontes, M. K., ... McFarland, W. (2008). An Empirical Comparison of Respondent-driven Sampling, Time Location Sampling, and Snowball Sampling for Behavioral Surveillance in Men Who Have Sex with Men, Fortaleza, Brazil. AIDS and Behavior, 12(S1), 97-104. https://doi.org/10.1007/s10461-008-9390-4

Kirby, T., \& Thornber-Dunwell, M. (2013). High-risk drug practices tighten grip on London gay scene. Lancet (London, England), 381(9861), 101-102. 
Lauby, J., Zhu, L., Milnamow, M., Batson, H., Bond, L., Curran-Groome, W., \& Carson, L. (2017). Get Real: Evaluation of a Community-Level HIV Prevention Intervention for Young MSM Who Engage in Episodic Substance Use. AIDS Education and Prevention: Official Publication of the International Society for AIDS Education, 29(3), 191-204. https://doi.org/10.1521/aeap.2017.29.3.191

Lea, T., de Wit, J., \& Reynolds, R. (2014). Minority Stress in Lesbian, Gay, and Bisexual Young Adults in Australia: Associations with Psychological Distress, Suicidality, and Substance Use. Archives of Sexual Behavior, 43(8), 15711578. https://doi.org/10.1007/s10508-014-0266-6

Lea, T., Kolstee, J., Lambert, S., Ness, R., Hannan, S., \& Holt, M. (2017). Methamphetamine treatment outcomes among gay men attending a LGBTIspecific treatment service in Sydney, Australia. PloS One, 12(2), e0172560. https://doi.org/10.1371/journal.pone.0172560

Lee, V. C., Sullivan, P. S., \& Baral, S. D. (2017). Global travel and HIV/STI epidemics among MSM: what does the future hold? Sexual Health, 14(1), 51. https://doi.org/10.1071/SH16099

Lhomond, B., Saurel-Cubizolles, M.-J., Michaels, S., \& CSF Group. (2014). A multidimensional measure of sexual orientation, use of psychoactive substances, and depression: results of a national survey on sexual behavior in france. Archives of Sexual Behavior, 43(3), 607-619. https://doi.org/10.1007/s10508-013-0124-y

Martinez, O., Arreola, S., Wu, E., Muñoz-Laboy, M., Levine, E. C., Rutledge, S. E., ... Sandfort, T. (2016). Syndemic factors associated with adult sexual HIV risk behaviors in a sample of Latino men who have sex with men in New York 
City. Drug and Alcohol Dependence, 166, 258-262.

https://doi.org/10.1016/j.drugalcdep.2016.06.033

Melendez-Torres, G. J., \& Bourne, A. (2016). Illicit drug use and its association with sexual risk behaviour among MSM: more questions than answers? Current Opinion in Infectious Diseases, 29(1), 58-63.

https://doi.org/10.1097/QCO.0000000000000234

Mercer, C. H., Prah, P., Field, N., Tanton, C., Macdowall, W., Clifton, S., ... Sonnenberg, P. (2016). The health and well-being of men who have sex with men (MSM) in Britain: Evidence from the third National Survey of Sexual Attitudes and Lifestyles (Natsal-3). BMC Public Health, 16, 525. https://doi.org/10.1186/s12889-016-3149-z

Mereish, E. H., Goldbach, J. T., Burgess, C., \& DiBello, A. M. (2017). Sexual orientation, minority stress, social norms, and substance use among racially diverse adolescents. Drug and Alcohol Dependence, 178, 49-56. https://doi.org/10.1016/j.drugalcdep.2017.04.013

Meyer, I. H. (2003). Prejudice, social stress, and mental health in lesbian, gay, and bisexual populations: Conceptual issues and research evidence. Psychological Bulletin, 129(5), 674-697. https://doi.org/10.1037/0033-2909.129.5.674

Mirandola, M., Gios, L., Davis, R. J., Furegato, M., Breveglieri, M., Folch, C., ... Stehlíková, D. (2017). Socio-demographic factors predicting HIV test seeking behaviour among MSM in 6 EU cities. European Journal of Public Health, 27(2), 313-318. https://doi.org/10.1093/eurpub/ckw144

Mirandola, M., Gios, L., Sherriff, N., Pachankis, J., Toskin, I., Ferrer, L., ... Sialon II Network. (2017). Socio-demographic Characteristics, Sexual and Test-Seeking Behaviours Amongst Men Who have Sex with Both Men and Women: Results 
from a Bio-behavioural Survey in 13 European Cities. AIDS and Behavior. https://doi.org/10.1007/s10461-017-1831-5

Mor, Z., \& Davidovich, U. (2016). Same-sex sexual attraction, behavior, and practices of Jewish men in Israel and the association with HIV prevalence. AIDS Care, 28(sup1), 64-67. https://doi.org/10.1080/09540121.2016.1146400

Ober, A., Shoptaw, S., Wang, P.-C., Gorbach, P., \& Weiss, R. E. (2009). Factors associated with event-level stimulant use during sex in a sample of older, lowincome men who have sex with men in Los Angeles. Drug and Alcohol Dependence, 102(1-3), 123-129.

https://doi.org/10.1016/j.drugalcdep.2009.02.002

Pachankis, J. E., Hatzenbuehler, M. L., Berg, R. C., Fernández-Dávila, P., Mirandola, M., Marcus, U., ... Schmidt, A. J. (2017). Anti-LGBT and Anti-Immigrant Structural Stigma: An Intersectional Analysis of Sexual Minority Men’s HIV Risk When Migrating to or Within Europe. Journal of Acquired Immune Deficiency Syndromes (1999).

https://doi.org/10.1097/QAI.0000000000001519

Pachankis, J. E., Hatzenbuehler, M. L., Hickson, F., Weatherburn, P., Berg, R. C., Marcus, U., \& Schmidt, A. J. (2015). Hidden from health: structural stigma, sexual orientation concealment, and HIV across 38 countries in the European MSM Internet Survey. AIDS (London, England), 29(10), 1239-1246. https://doi.org/10.1097/QAD.0000000000000724

Pachankis, J. E., Hatzenbuehler, M. L., Mirandola, M., Weatherburn, P., Berg, R. C., Marcus, U., \& Schmidt, A. J. (2017). The Geography of Sexual Orientation: Structural Stigma and Sexual Attraction, Behavior, and Identity Among Men 
Who Have Sex with Men Across 38 European Countries. Archives of Sexual Behavior, 46(5), 1491-1502. https://doi.org/10.1007/s10508-016-0819-y

Petersson, F. J. M., Tikkanen, R., \& Schmidt, A. J. (2016). Party and Play in the Closet? Exploring Club Drug Use Among Swedish Men Who Have Sex With Men. Substance Use \& Misuse, 51(9), 1093-1103. https://doi.org/10.3109/10826084.2016.1160117

Rabe-Hesketh, S., Skrondal, A., \& Skrondal, A. (2008). Multilevel and longitudinal modeling using stata (2nd ed). College Station, Tex: Stata Press Publication. Santos, G.-M., Coffin, P. O., Das, M., Matheson, T., DeMicco, E., Raiford, J. L., ... Herbst, J. H. (2013). Dose-response associations between number and frequency of substance use and high-risk sexual behaviors among HIVnegative substance-using men who have sex with men (SUMSM) in San Francisco. Journal of Acquired Immune Deficiency Syndromes (1999), 63(4), 540-544. https://doi.org/10.1097/QAI.0b013e318293f10b

Santos, G.-M., Do, T., Beck, J., Makofane, K., Arreola, S., Pyun, T., ... Ayala, G. (2014). Syndemic conditions associated with increased HIV risk in a global sample of men who have sex with men. Sexually Transmitted Infections, 90(3), 250-253. https://doi.org/10.1136/sextrans-2013-051318

Schmidt, A. J., Bourne, A., Weatherburn, P., Reid, D., Marcus, U., \& Hickson, F. (2016). Illicit drug use among gay and bisexual men in 44 cities: Findings from the European MSM Internet Survey (EMIS). International Journal of Drug Policy, 38, 4-12. https://doi.org/10.1016/j.drugpo.2016.09.007

Sewell, J., Miltz, A., Lampe, F. C., Cambiano, V., Speakman, A., Phillips, A. N., ... Rodger, A. J. (2017). Poly drug use, chemsex drug use, and associations with sexual risk behaviour in HIV-negative men who have sex with men attending 
sexual health clinics. International Journal of Drug Policy, 43, 33-43.

https://doi.org/10.1016/j.drugpo.2017.01.001

Singer, M., Bulled, N., Ostrach, B., \& Mendenhall, E. (2017). Syndemics and the biosocial conception of health. The Lancet, 389(10072), 941-950. https://doi.org/10.1016/S0140-6736(17)30003-X

Stall, R., Mills, T. C., Williamson, J., Hart, T., Greenwood, G., Paul, J., ... Catania, J. A. (2003). Association of co-occurring psychosocial health problems and increased vulnerability to HIV/AIDS among urban men who have sex with men. American Journal of Public Health, 93(6), 939-942.

The Sialon II Project. (2016). Report on a Bio-behavioural Survey among MSM in 13 European cities. Cierre Grafica.

Tieu, H.-V., Nandi, V., Frye, V., Stewart, K., Oquendo, H., Bush, B., ... NYC M2M Study Team. (2014). Concurrent partnerships and HIV risk among men who have sex with men in New York City. Sexually Transmitted Diseases, 41(3), 200-208. https://doi.org/10.1097/OLQ.0000000000000090

Vanden Berghe, W., Nöstlinger, C., Hospers, H., \& Laga, M. (2013). International mobility, sexual behaviour and HIV-related characteristics of men who have sex with men residing in Belgium. BMC Public Health, 13(1). https://doi.org/10.1186/1471-2458-13-968

Vanden Berghe, W., Nöstlinger, C., \& Laga, M. (2014). Syndemic and other risk factors for unprotected anal intercourse among an online sample of Belgian HIV negative men who have sex with men. AIDS and Behavior, 18(1), 50-58. https://doi.org/10.1007/s10461-013-0516-y

Vosburgh, H. W., Mansergh, G., Sullivan, P. S., \& Purcell, D. W. (2012). A review of the literature on event-level substance use and sexual risk behavior among 
men who have sex with men. AIDS and Behavior, 16(6), 1394-1410. https://doi.org/10.1007/s10461-011-0131-8

Wall, K. M., Stephenson, R., \& Sullivan, P. S. (2013). Frequency of Sexual Activity With Most Recent Male Partner Among Young, Internet-Using Men Who Have Sex With Men in the United States. Journal of Homosexuality, 60(10), 1520-1538. https://doi.org/10.1080/00918369.2013.819256

Weatherburn, P., Hickson, F., Reid, D., Torres-Rueda, S., \& Bourne, A. (2017). Motivations and values associated with combining sex and illicit drugs ('chemsex') among gay men in South London: findings from a qualitative study. Sexually Transmitted Infections, 93(3), 203-206. https://doi.org/10.1136/sextrans-2016-052695

Wilson, P. A., Valera, P., Martos, A. J., Wittlin, N. M., Muñoz-Laboy, M. A., \& Parker, R. G. (2016). Contributions of Qualitative Research in Informing HIV/AIDS Interventions Targeting Black MSM in the United States. The Journal of Sex Research, 53(6), 642-654.

https://doi.org/10.1080/00224499.2015.1016139

Wohl, A. R., Frye, D. M., \& Johnson, D. F. (2008). Demographic characteristics and sexual behaviors associated with methamphetamine use among MSM and nonMSM diagnosed with AIDS in Los Angeles County. AIDS and Behavior, 12(5), 705-712. https://doi.org/10.1007/s10461-007-9315-7 


\section{Annex I. The Sialon II Network}

Massimo Mirandola, Lorenzo Gios, Stefano Benvenuti, Ruth Joanna Davis, Massimo Lunardi, Silvana Menichelli, Michele Breveglieri, Martina Furegato, (Coordinamento Regionale per il Management e la Progettazione Europea, Azienda Ospedaliera Universitaria Integrata, Verona, Italy)

Wim Vanden Berghe, Peter de Groot, Christiana Nöstlinger, Veronica van Wijk, Katrien Fransen, Tine Vermoesen, Michiel Vanackere (Institute of Tropical Medicine, ITG, Antwerp, Belgium)

Fourat Benchikha, Sandra Van den Eynde, Boris Cruyssaert, Mark Sergeant, Karel Blondeel, Pieter Damen (Sensoa, Antwerp, Belgium)

François Massoz, Erwin Carlier (Rainbowhouse Brussels, Belgium)

Michael François, Stephen Karon (Ex Aequo, Belgium)

Safia Soltani, Thierry Martin (Belgium)

Alan De Bruyne (The Belgian Pride, Belgium)

Francoise Bocken (Alias, Belgium)

Myriam Dieleman (Observatoire du sida et des sexualités, Belgium)

Ivailo Alexiev, Reneta Dimitrova, Anna Gancheva, Dobromira Bogeva, Maria

Nikolova, Mariya Muhtarova, Todor Kantarjiev, (National Center of Infectious and Parasitic Diseases, Sofia, Bulgaria)

Viara Georgieva (National Center of Infectious and Parasitic Diseases, Sofia, Bulgaria; Ministry of Health, Sofia, Bulgaria)

Emilia Naseva, Petar Tsintsarski, Hristo Taskov, Tonka Varleva (Program “Prevention and Control of HIV/AIDS”, Ministry of Health, Sofia, Bulgaria) 
Elena Birindjieva, Aneliya Angelova, Manol Antonov (Association “Health without borders”, Bulgaria)

Ulrich Marcus, Susanne Barbara Schink, Sandra Dudareva-Vizule, Matthias an der Heiden, Sami Marzougui, Viviane Bremer, Andrea Kühne, Kerstin SchönerstedtZastrau, Ruth Zimmermann (Robert Koch Institute, Berlin, Germany)

Andreas Wille (Institut für Hygiene und Umwelt, Hamburg, Germany)

Kai Eckstein, Norman Buch, Philipp Moskophidis, Marc Grenz, Danilo Schmogro, (Hein \& Fiete, Hamburg, Germany)

Giuseppe Cornaglia, Antonella Zorzi, Elisabetta Tonolli, Giuliana Lo Cascio, Teresa Todeschini, Manuela Recchia, Lorella Pattini, Maria Rocca, Alessandra Bighignoli, Anita Galardi, Loredana Martini, Sandro Caffi, Pier Paolo Benetollo, Francesco Cobello, Chiara Bovom, Umberta Benvenuti (Azienda Ospedaliera Universitaria Integrata, Verona, Italy)

Giulia Bisoffi, Oscar Bortolami, Laura Crestani (Unità Supporto alla Ricerca e Biostatistica, Azienda Ospedaliera Universitaria Integrata, Verona, Italy) Fabiano Comperini (Italy)

Ercole Concia, Emanuela Lattuada, Massimiliano Lanzafame, Stefania Leonardi, Paola Del Bravo (Infectious Diseases Section, Department of Pathology-Verona University Hospital - Veneto Region, Verona, Italy) Maddalena Cordioli, Fabio Rigo, Emanuele Guardalben, Ivan Marchesoni (Università degli studi di Verona, Verona, Italy)

Barbara Suligoi, Vincenza Regine, Lucia Pugliese (Centro Operativo AIDS, Istituto Superiore di Sanità, Rome, Italy) 
Saulius Caplinskas, Irma Caplinskiene, Rima Krupenkaite (Centre for

Communicable Diseases and AIDS, Vilnius, Lithuania)

Gediminas Sargelis, Arturas Rudomanskis, (“Tolerant Youth Association”, Vilnius, Lithuania)

Sónia Dias, Ana Gama, Oriana Brás (Global Health and Tropical Medicine, GHTM, Instituto de Higiene e Medicina Tropical, IHMT, Universidade Nova de Lisboa, Portugal)

João Piedade (Medical Microbiology Unit, Instituto de Higiene e Medicina Tropical, Lisbon, Portugal)

Ricardo Fuertes, Nuno Pinto, João Brito, Júlio Esteves, Jesus Rojas, Fernando Ferreira, Miguel Rocha, Hugo Machado, Maria José Campos, (CheckpointLX, Portugal)

Luís Mendão (GAT, Grupo Português de Ativistas sobre Tratamentos de VIH/SIDA - Pedro Santos, Portugal)

Magdalena Rosińska, Bożena Kucharczyk, Marta Niedźwiedzka-Stadnik, Łukasz Henszel, Andrzej Zieliński, Michał Czerwiński, (NIZP-PZH, Warsaw, Poland) Michał Pawlęga, Ewelina Burdon, Małgorzata Gajdemska, Agnieszka Guściora, Nikodem Klasik, Katarzyna Rżanek, Michał Sawicki, Michał Tęcza, Ewelina Burdon, Małgorzata Gajdemska, Agnieszka Guściora, Nikodem Klasik, Katarzyna Rżanek , (Lambda Warszawa, Warsaw, Poland)

Mateusz Dębski, Anna Maciejewska, Izabela Pazdan (SKA Warsaw, Poland) Izabela Pazdan (SKA, VCT side, Warsaw, Poland) 
Alexandru Rafila, Daniela Pitigoi, Adrian Abagiu (National Institute for infectious Diseases Prof. Dr. Matei Bals, Bucharest, Romania)

Carolina Marin, Ioana Panzariu, Alexandru Miroiu, (ACCEPT Association, Bucharest, Romania)

Madalina Popa, Monica Likker (National Institute for infectious Diseases Prof. Dr. Matei Bals, Bucharest, Romania)

Maria Georgescu, Galina Musat, Dan Cojocaru, Mihai Lixandru, Raluca Teodorescu (Romanian Anti-AIDS Association - ARAS, Bucharest, Romania)

Danica Staneková, Monika Hábeková, Tatiana Drobková, Zuzana Chabadová, Soňa Wimmerova, Maria Mojzesová (Slovak Medical University, NRC for HIV/AIDS prevention, Bratislava, Slovakia)

Filip Kunč, Michal Skurák, Peter Bodnar, Katarína Horniaková, Mária Krahulcová, Jarmila Präsensová (Slovakia)

Martin Smoleň, Peter Záhradník, Pavol Tibaj （NGO Dúhové srdce, Bratislava, Slovakia)

Irena Klavs, Tanja Kustec, Claudia Adamič (National Institute of Public health, Ljubljana, Slovenia)

Mario Poljak, Robert Krošelj, Jana Mlakar (Institute of Microbiology and Imunology, Medical faculty, University of Ljubljana, Ljubljana, Slovenia) Miran Šolinc (Association SKUC, Ljubljana, Slovenia) 
Cinta Folch, Laia Ferrer, Alexandra Montoliu,Jordi Casabona, Anna Esteve, Montserrat Galdon (Centre for Epidemiological Studies on HIV/STI in Catalonia CEEISCAT, Agència de Salut Pública de Catalunya, Barcelona, Spain)

Victoria Gonzalez (Microbiology Service, Hospital Universitari Germans Trias i Pujol, Barcelona, Spain)

Rafael Muñoz (StopSida, Barcelona, Spain)

Maria Axelsson, Torsten Berglund, Sharon Kuhlmann-Berenzon, Achilleas Tsoumanis, Inga Velicko, Christer Janson, Bartek Lindh, Kajsa Aperia (Public Health Agency of Sweden, Stockholm, Sweden)

Buddha Babulanam, Hans Carlberg, Malte Davidsson, Nedo Entenza Gutierrez, Viktor Hildingsson, Henrik Klasson, Moises Peña Ramos, Cristian Quintero Rojas, Sven-Olof Sandberg, Andreas Samuelson,Eric Sjöberg, Tommy Sjölund,Simon Svensson, Iván Valencia (Sweden)

Filip Garcia, Olov Lindblad (RFSL Stockholm, Sweden)

Jon Voss (Stockholm Gay Life, Sweden)

Ronnie Ask, Anders Blaxhult, Maarit Maliniemi, (Venhälsan, Stockholm South

General Hospital, Stockholm, Sweden)

Monica Ideström, Nils Blom (Public Health Agency of Sweden, Stockholm, Sweden)

Nigel Sherriff, Christina Panton, Glynis Flood (Centre for Health Research CHR, University of Brighton, Brighton, UK) 
Katrien Fransen, Tine Vermoesen (Aids reference laboratory, Institute of Tropical Medicine, Antwerp, Belgium)

Ross Boseley, Marc Tweed (Terrence Higgins Trust, South, UK)

Jonathon Roberts (Claude Nicol Centre, Royal Sussex County Hospital, Brighton, $\mathrm{UK})$

Cinthia Menel Lemos (Executive Agency for Health and Consumers)

Paolo Guglielmetti, Wolfgang Philipp, Matthias Schuppe (DG SANTE)

Andrew Amato, Irina Dinca, Karin Haar, Anastasia Pharris, Teymur Noori

(European Centre for Disease Prevention and Control ECDC)

Igor Toskin, Armando Seuc, Natalie Maurer (Department of Reproductive Health \& Research of the World Health Organization WHO)

Lev Zohrabyan, Alexandrina Iovita, Maddalena Campioni, Patrick Noack (Joint United Nations Programme on HIV/AIDS UNAIDS)

Rosanna Peeling (London School of Hygiene and Tropical Medicine)

Lisa Johnston (USA) 
Table 1. Characteristics of the study population, including total population and by drug used during last sexual encounter associated with anal sex, Sialon II.

\begin{tabular}{|c|c|c|c|c|c|c|c|c|c|}
\hline & & Total & $\begin{array}{l}\text { No drug } \\
\text { reported }\end{array}$ & $\begin{array}{l}\text { Any drug } \\
\text { reported }\end{array}$ & $\begin{array}{l}\text { Sexual } \\
\text { performa } \\
\text { nce drug } \\
\text { reported }\end{array}$ & $\begin{array}{l}\text { Party } \\
\text { drug } \\
\text { reported }\end{array}$ & $\begin{array}{l}\text { Chemsex } \\
\text { drug } \\
\text { reported }\end{array}$ & $\begin{array}{l}\text { Alcohol } \\
\text { reported }\end{array}$ & $\begin{array}{l}\text { Cannabis } \\
\text { reported }\end{array}$ \\
\hline Total & & 4266 & 2941 & 1261 & 966 & 353 & 142 & 1904 & 331 \\
\hline Age (years) & mean/SD; median (IQR) & $\begin{array}{l}33.7 / 10.7 \\
32(25-40)\end{array}$ & $\begin{array}{l}33.4 / 10.6 ; 31 \\
(25-39)\end{array}$ & $\begin{array}{l}34.6(10.8) \\
33(26-42)\end{array}$ & $\begin{array}{l}35.7 / 10.9 \\
34(27-43)\end{array}$ & $\begin{array}{l}32.2 / 9.1 \\
32(22-40)\end{array}$ & $\begin{array}{l}32.2 / 8.7 ; 32 \\
(25-37)\end{array}$ & $\begin{array}{l}32.4 / 9.8 ; 30 \\
(25-38)\end{array}$ & $\begin{array}{l}30.9 / 9.8 \\
29(23-36)\end{array}$ \\
\hline \multirow[t]{6}{*}{ Age group } & $18-24$ & $887(20.8)$ & 643 (21.9) & $232(18.4)$ & $142(14.7)$ & $75(21.3)$ & $30(21.1)$ & $433(22.8)$ & $102(30.8)$ \\
\hline & $25-34$ & 1698 (39.8) & 1171 (39.9) & 497 (39.4) & 381 (39.4) & 156 (44.3) & $64(45.1)$ & 833 (43.8) & $134(40.5)$ \\
\hline & $35-44$ & $989(23.2)$ & $688(23.4)$ & 286 (22.7) & $236(24.4)$ & $80(22.7)$ & 34 (23.9) & $390(20.5)$ & $56(16.9)$ \\
\hline & $45-54$ & 483 (11.3) & 302 (10.3) & 177 (14.0) & $146(15.1)$ & $36(10.2)$ & $13(9.2)$ & $183(9.6)$ & 32 (9.7) \\
\hline & $55+$ & $205(4.8)$ & $134(4.6)$ & $68(5.4)$ & $61(6.3)$ & $5(1.4)$ & $1(0.7)$ & $64(3.4)$ & $7(2.1)$ \\
\hline & Missing & 4 & 3 & 1 & 0 & 1 & 0 & 1 & 0 \\
\hline \multirow[t]{5}{*}{ Migration Status } & native: born \& live in the study country & $3463(81.4)$ & $2408(82.0)$ & 996 (79.4) & 765 (79.7) & $255(73.1)$ & $96(68.6)$ & $1531(80.7)$ & $259(78.2)$ \\
\hline & $\begin{array}{l}\text { emigrant: born in the study country \& } \\
\text { live abroad }\end{array}$ & $55(1.3)$ & $37(1.3)$ & $18(1.4)$ & $11(1.1)$ & $4(1.1)$ & $2(1.4)$ & $29(1.5)$ & $5(1.5)$ \\
\hline & $\begin{array}{l}\text { immigrant: born abroad \& live in the } \\
\text { study country }\end{array}$ & $520(12.2)$ & 348 (11.9) & 169 (13.5) & $127(13.2)$ & $67(19.2)$ & 25 (17.9) & $233(12.3)$ & $48(14.5)$ \\
\hline & visitor: born \& live abroad & $214(5.0)$ & $142(4.8)$ & $71(5.7)$ & $57(5.9)$ & $23(6.6)$ & $17(12.1)$ & $105(5.5)$ & $19(5.7)$ \\
\hline & Missing & 14 & 6 & 7 & 6 & 4 & 4 & 6 & 0 \\
\hline \multirow[t]{4}{*}{ Education } & secondary or lower & $268(6.4)$ & $159(5.5)$ & $101(8.2)$ & $68(7.2)$ & $43(12.7)$ & $6(4.4)$ & $131(7.0)$ & $47(14.8)$ \\
\hline & $\begin{array}{l}\text { high school or post secondary education } \\
\text { (vocational school or college) }\end{array}$ & $1610(38.6)$ & 1075 (37.3) & $502(40.9)$ & $372(39.2)$ & $131(38.6)$ & $39(28.5)$ & $744(40.0)$ & 139 (43.7) \\
\hline & university studies or degree & $2295(55.0)$ & $1650(57.2)$ & 625 (50.9) & $509(53.6)$ & 165 (48.7) & $92(67.2)$ & $987(53.0)$ & $132(41.5)$ \\
\hline & Missing & 93 & 57 & 33 & 17 & 14 & 5 & 42 & 13 \\
\hline \multirow[t]{3}{*}{ Outness } & out to less than half & $1737(42.1)$ & $1261(44.5)$ & $448(36.2)$ & $337(35.5)$ & $114(33.2)$ & $21(15.3)$ & $784(42.1)$ & $94(28.9)$ \\
\hline & out to majority & 2385 (57.9) & $1571(55.5)$ & 789 (63.8) & $612(64.5)$ & $229(66.8)$ & $116(84.7)$ & 1077 (57.9) & $231(71.1)$ \\
\hline & Missing & 144 & 109 & 24 & 17 & 10 & 5 & 43 & 6 \\
\hline
\end{tabular}




\begin{tabular}{|c|c|c|c|c|c|c|c|c|c|}
\hline \multirow{3}{*}{$\begin{array}{l}\text { Attitude towards } \\
\text { MSM at work/school }\end{array}$} & Negative & 1195 (29.1) & 842 (29.8) & $333(27.1)$ & $240(25.6)$ & $94(27.6)$ & $29(21.0)$ & $557(30.0)$ & $83(25.4)$ \\
\hline & neutral or positive & 2916 (70.9) & $1987(70.2)$ & $895(72.9)$ & $698(74.4)$ & $247(72.4)$ & $109(79.0)$ & $1300(70.0)$ & 244 (74.6) \\
\hline & Missing & 155 & 112 & 33 & 28 & 12 & 4 & 1857 & 327 \\
\hline \multirow{3}{*}{$\begin{array}{l}\text { Attitude towards } \\
\text { MSM by parents }\end{array}$} & Negative & 1161 (28.9) & 824 (29.9) & 320 (26.5) & $228(24.6)$ & $101(30.6)$ & $27(20.1)$ & $523(28.7)$ & 77 (23.9) \\
\hline & neutral or positive & 2850 (71.1) & $1933(70.1)$ & $886(73.5)$ & $698(75.4)$ & $229(69.4)$ & 107 (79.9) & $1298(71.3)$ & $245(76.1)$ \\
\hline & Missing & 255 & 184 & 55 & 40 & 23 & 8 & 83 & 9 \\
\hline \multirow{3}{*}{$\begin{array}{l}\text { Attitude towards } \\
\text { MSM by } \\
\text { friends/acquaintances }\end{array}$} & Negative & 315 (7.8) & $218(7.8)$ & $88(7.3)$ & $63(6.8)$ & $27(8.2)$ & $4(3.0)$ & $146(7.9)$ & $24(7.5)$ \\
\hline & neutral or positive & 3741 (92.2) & $2582(92.2)$ & $1120(92.7)$ & $870(93.2)$ & $301(91.8)$ & $131(97.0)$ & $1691(92.1)$ & $296(92.5)$ \\
\hline & Missing & 210 & 141 & 53 & 33 & 25 & 7 & 67 & 11 \\
\hline \multirow{4}{*}{$\begin{array}{l}\text { Declared HIV status } \\
\text { independent of test } \\
\text { result }\end{array}$} & HIV positive & $253(5.9)$ & $116(3.9)$ & $132(10.5)$ & $116(12.0)$ & $43(12.2)$ & $25(17.6)$ & $121(6.4)$ & $28(8.5)$ \\
\hline & HIV negative & 3154 (73.9) & $2200(74.8)$ & 931 (73.8) & $720(74.5)$ & $255(72.2)$ & 109 (76.8) & $1440(75.6)$ & $235(71.0)$ \\
\hline & Other & 859 (20.1) & $625(21.3)$ & 198 (15.7) & $130(13.5)$ & $55(15.6)$ & $8(5.6)$ & 343 (18.0) & 68 (20.5) \\
\hline & Missing & 0 & 0 & 0 & 0 & 0 & 0 & 0 & 0 \\
\hline \multirow{3}{*}{$\begin{array}{l}\text { Relationships with } \\
\text { women and men, last } 6 \\
\text { months }\end{array}$} & male only & 3499 (87.3) & $2461(89.2)$ & $1016(84.0)$ & 799 (86.5) & 263 (78.5) & 119 (87.5) & $1571(85.4)$ & $240(75.9)$ \\
\hline & female and male partners & $508(12.7)$ & $299(10.8)$ & $193(16.0)$ & 125 (13.5) & $72(21.5)$ & $17(12.5)$ & $269(14.6)$ & $76(24.1)$ \\
\hline & Missing & 259 & 181 & 52 & 42 & 18 & 6 & 64 & 15 \\
\hline \multirow[t]{3}{*}{ Ever injected drugs } & No & $3681(95.6)$ & $2639(97.4)$ & $1016(92.3)$ & 793 (93.5) & $242(83.7)$ & $89(80.2)$ & $1628(94.1)$ & $262(90.3)$ \\
\hline & Yes & $168(4.4)$ & $71(2.6)$ & $85(7.7)$ & $55(6.5)$ & $47(16.3)$ & $22(19.8)$ & $102(5.9)$ & $28(9.7)$ \\
\hline & Missing & 417 & 231 & 160 & 118 & 64 & 31 & 1730 & 290 \\
\hline \multirow{3}{*}{$\begin{array}{l}\text { Diagnosis of STIs in } \\
\text { the last } 12 \text { months }\end{array}$} & No & 3774 (88.5) & $2671(90.8)$ & $1051(83.3)$ & 791 (81.9) & $281(79.6)$ & $104(73.2)$ & $1644(86.3)$ & $281(84.9)$ \\
\hline & Yes & $492(11.5)$ & $270(9.2)$ & $210(16.7)$ & $175(18.1)$ & $72(20.4)$ & 38 (26.8) & $260(13.7)$ & $50(15.1)$ \\
\hline & Missing & 0 & 0 & 0 & 0 & 0 & 0 & 0 & 0 \\
\hline $\begin{array}{l}\text { Satisfaction with own } \\
\text { sexual life }\end{array}$ & Not very satisfied & 2708 (67.8) & $1870(68.1)$ & $822(67.8)$ & $617(66.0)$ & $212(63.3)$ & $77(55.8)$ & $1291(70.4)$ & 207 (66.1) \\
\hline
\end{tabular}




\begin{tabular}{|c|c|c|c|c|c|c|c|c|c|}
\hline & Very satisfied & $1286(32.2)$ & 877 (31.9) & $390(32.2)$ & $318(34.0)$ & $123(36.7)$ & $61(44.2)$ & 543 (29.6) & 106 (33.9) \\
\hline & Missing & 272 & 194 & 49 & 31 & 18 & 4 & 70 & 18 \\
\hline \multirow{4}{*}{$\begin{array}{l}\text { Last anal intercourse } \\
\text { with }\end{array}$} & steady partner & $1873(47.6)$ & $1398(51.8)$ & $457(38.1)$ & 337 (36.6) & $127(38.6)$ & $52(40.0)$ & $760(41.8)$ & $133(42.4)$ \\
\hline & non-steady partner & $1813(46.1)$ & 1212 (44.9) & $587(49.0)$ & $443(48.1)$ & $149(45.3)$ & 49 (37.7) & 899 (49.5) & $145(46.2)$ \\
\hline & more than one partner & $246(6.3)$ & $89(3.3)$ & 154 (12.9) & $141(15.3)$ & $53(16.1)$ & $29(22.3)$ & $158(8.7)$ & 36 (11.5) \\
\hline & Missing & 334 & 242 & 63 & 45 & 24 & 12 & 87 & 17 \\
\hline $\begin{array}{l}\text { Number of gay venues } \\
\text { attended during the } \\
\text { past } 3 \text { months }\end{array}$ & mean/SD; median (IQR) & $\begin{array}{l}18.8 / 42.2 ; 7 \\
(2-20)\end{array}$ & $\begin{array}{l}16.7 / 39.9 ; 6 \\
(2-17)\end{array}$ & $\begin{array}{l}23.7 / 46.9 ; 11 \\
(3-26.5)\end{array}$ & $\begin{array}{l}22.9 / 48.1 ; \\
11(1-25)\end{array}$ & $\begin{array}{l}29.9 / 49.0 \\
15(5-34)\end{array}$ & $\begin{array}{l}25.3 / 33.7 ; 13 \\
.5(4.5-28.5)\end{array}$ & $\begin{array}{l}22.9 / 48.9 \\
10(3-25)\end{array}$ & $\begin{array}{l}\text { 25.3/50.5; } \\
10(3-29)\end{array}$ \\
\hline
\end{tabular}


Table 2. Substance use during last sexual encounter associated with anal intercourse, by study site, Sialon II

\begin{tabular}{|c|c|c|c|c|c|c|c|c|}
\hline Study site & $\begin{array}{l}\text { Any } \\
\text { substance } \\
(n, \%)^{*}\end{array}$ & $\begin{array}{l}\text { Any drug } \\
(n, \%)\end{array}$ & $\begin{array}{l}\text { Alcohol } \\
(n, \%)\end{array}$ & $\begin{array}{l}\text { Cannabis } \\
(\mathrm{n}, \%)\end{array}$ & $\begin{array}{l}\text { Pperformanc } \\
\text { e drugs }(n, \%)\end{array}$ & $\begin{array}{l}\text { Party drugs } \\
(\mathrm{N}, \%)\end{array}$ & $\begin{array}{l}\text { Chemsex } \\
\text { drugs } \\
(\mathrm{n}, \%)\end{array}$ & $\begin{array}{l}\text { Number of } \\
\text { substances } \\
\text { among those } \\
\text { who used any } \\
\text { (mean/SD, } \\
\text { median (IQR) }\end{array}$ \\
\hline Barcelona & 198(55.9) & $135(38.1)$ & $146(41.2)$ & $56(15.8)$ & $101(28.5)$ & $54(15.3)$ & $16(4.5)$ & $2.1 / 1.6,1(1-2)$ \\
\hline Bratislava & $172(50.4)$ & $78(22.9)$ & $133(39.0)$ & $23(6.7)$ & 67 (19.6) & $9(2.6)$ & $1(0.3)$ & $1.4 / .7,1(1-2)$ \\
\hline Brighton & $218(67.7)$ & $138(42.9)$ & $179(55.6)$ & $23(7.2)$ & $120(37.3)$ & $42(13.0)$ & $30(9.3)$ & $2.0 / 1.4,2(1-3)$ \\
\hline Brussels & $243(71.5)$ & $180(52.9)$ & 179(52.6) & 39 (11.5) & $146(42.9)$ & $72(21.2)$ & 47 (13.9) & $2.3 / 1.6,2(1-3)$ \\
\hline Bucharest & $74(48.1)$ & $25(17.7)$ & $68(45.3)$ & $8(5.9)$ & $11(8.3)$ & $13(8.4)$ & $0(0.0)$ & $1.4 / .8,1(1-2)$ \\
\hline Hamburg & 192(58.7) & $115(35.2)$ & $157(48.0)$ & $26(8.0)$ & 99 (30.3) & $17(5.2)$ & $4(1.2)$ & $1.7 / 1.0,1(1-2)$ \\
\hline Lisbon & $159(44.2)$ & $81(22.5)$ & $120(33.3)$ & $28(7.8)$ & $48(13.4)$ & $19(5.3)$ & $7(1.9)$ & $1.5 / 1.0,1(1-2)$ \\
\hline Ljubljana & $184(54.9)$ & $92(27.5)$ & $154(46.0)$ & $40(12.0)$ & $59(17.6)$ & $29(8.7)$ & $20(6.0)$ & $1.8 / 1.4,1(1-2)$ \\
\hline Sofia & $270(65.7)$ & $146(35.7)$ & $245(59.6)$ & $23(5.6)$ & $103(25.3)$ & $42(10.2)$ & $2(0.5)$ & $1.6 / .7,1(1-2)$ \\
\hline Stockholm & $122(41.9)$ & $59(20.3)$ & $95(32.6)$ & $4(1.4)$ & $54(18.6)$ & $9(3.1)$ & $1(0.3)$ & $1.5 / .9,1(1-2)$ \\
\hline Verona & $112(31.2)$ & $56(15.6)$ & $85(23.8)$ & $33(9.2)$ & $22(6.1)$ & $16(4.5)$ & $3(0.8)$ & $1.5 / 1.0,1(1-2)$ \\
\hline Vilnius & $158(55.2)$ & $37(12.9)$ & $151(52.8)$ & $9(3.1)$ & $30(10.5)$ & $7(2.4)$ & $1(0.3)$ & $1.3 / .9,1(1-1)$ \\
\hline Warsaw & $223(66.4)$ & $119(35.4)$ & 192(57.5) & $19(5.7)$ & $106(31.5)$ & $24(7.1)$ & $10(3.0)$ & $1.7 / 1.1,1(1-2)$ \\
\hline Total & $2325(55.1)$ & $1261(30.0)$ & $1904(45.2)$ & 331 (7.9) & $966(23.1)$ & $353(8.4)$ & $142(3.4)$ & $1.7 / 1.2,1(1-2)$ \\
\hline $\begin{array}{l}p \text {-value for } \\
\text { difference } \\
\text { between } \\
\text { sites }\end{array}$ & $<0.001$ & $<0.001$ & $<0.001$ & $<0.001$ & $<0.001$ & $<0.001$ & $<0.001$ & $<0.001$ \\
\hline
\end{tabular}

* percent calculated with respect to non-missing observations 
Table 3. Factors related to substance use during last sexual encounter associated with anal sex, by substance type. Results of multivariable analysis, Sialon II

\begin{tabular}{|c|c|c|c|c|c|c|c|c|c|c|c|}
\hline & & \multicolumn{2}{|l|}{ Party drugs } & \multicolumn{2}{|c|}{ Performance drugs } & \multicolumn{2}{|l|}{ Chemsex drugs } & \multicolumn{2}{|l|}{ Alcohol } & \multicolumn{2}{|l|}{ Cannabis } \\
\hline & & $\begin{array}{l}\text { Adjusted Odds } \\
\text { Ratio* }(95 \% \mathrm{Cl})\end{array}$ & $\begin{array}{l}p- \\
\text { value }\end{array}$ & $\begin{array}{l}\text { Adjusted Odds } \\
\text { Ratio* }(95 \% \mathrm{Cl})\end{array}$ & $\begin{array}{l}p- \\
\text { value }\end{array}$ & $\begin{array}{l}\text { Adjusted Odds } \\
\text { Ratio* }(95 \% \mathrm{Cl})\end{array}$ & $\begin{array}{l}p- \\
\text { value }\end{array}$ & $\begin{array}{l}\text { Adjusted Odds } \\
\text { Ratio* }(95 \% \mathrm{Cl})\end{array}$ & $\begin{array}{l}p \text { - } \\
\text { value }\end{array}$ & $\begin{array}{l}\text { Adjusted Odds } \\
\text { Ratio* }(95 \% \mathrm{Cl})\end{array}$ & $\begin{array}{l}p- \\
\text { value }\end{array}$ \\
\hline Age & $\begin{array}{l}\text { (per } 10 \text { years } \\
\text { increase) }\end{array}$ & $0.98(0.97-1)$ & 0.046 & $1.02(1.01-1.03)$ & 0.000 & $\begin{array}{l}0.95(0.93- \\
0.97)\end{array}$ & 0.000 & $0.98(0.97-0.99)$ & 0.000 & $0.97(0.95-0.98)$ & 0.000 \\
\hline \multirow[t]{2}{*}{ Migration status } & Mobile & $1.6(1.1-2.3)$ & 0.010 & $=\#$ & & - & & $1.5(1.2-1.8)$ & 0.000 & - & \\
\hline & Native & Ref. & & & & & & Ref. & & & \\
\hline \multirow[t]{2}{*}{ Education } & University & $0.7(0.5-0.95)$ & 0.022 & $0.8(0.7-0.9)$ & 0.008 & $1.8(1.1-2.9)$ & 0.016 & $0.82(0.7-0.95)$ & 0.009 & $0.6(0.5-0.8)$ & 0.000 \\
\hline & Lower & Ref. & & Ref. & & Ref. & & Ref. & & Ref. & \\
\hline \multirow[t]{2}{*}{ Outness } & Out to majority & $2.0(1.4-2.8)$ & 0.000 & - & & $2.3(1.3-4.2)$ & 0.005 & - & & $2.5(1.8-3.4)$ & 0.000 \\
\hline & $\begin{array}{l}\text { Out to less } \\
\text { than half }\end{array}$ & Ref. & & & & Ref. & & & & Ref. & \\
\hline \multirow{2}{*}{$\begin{array}{l}\text { Attitude towards } \\
\text { MSM by } \\
\text { parents/family }\end{array}$} & Negative & $1.4(1.1-2.0)$ & 0.025 & - & & - & & - & & - & \\
\hline & $\begin{array}{l}\text { Neutral or } \\
\text { positive }\end{array}$ & Ref. & & & & & & & & & \\
\hline \multirow[t]{2}{*}{$\begin{array}{l}\text { Self-reported HIV } \\
\text { status }\end{array}$} & $\begin{array}{l}\text { Diagnosed with } \\
\text { HIV }\end{array}$ & - & & $2.0(1.4-2.8)$ & 0.000 & - & & - & & - & \\
\hline & $\begin{array}{l}\text { Not diagnosed } \\
\text { with HIV }\end{array}$ & & & Ref. & & & & & & & \\
\hline $\begin{array}{l}\text { Relationships with } \\
\text { women and men, } \\
\text { last } 6 \text { months }\end{array}$ & $\begin{array}{l}\text { female and } \\
\text { male }\end{array}$ & $2.2(1.5-3.2)$ & 0.000 & $1.4(1.0-1.8)$ & 0.023 & - & & $1.5(1.2-1.8)$ & 0.001 & $3.2(2.2-4.5)$ & 0.000 \\
\hline
\end{tabular}




\begin{tabular}{|c|c|c|c|c|c|c|c|c|c|c|c|}
\hline & & \multicolumn{2}{|l|}{ Party drugs } & \multicolumn{2}{|c|}{ Performance drugs } & \multicolumn{2}{|l|}{ Chemsex drugs } & \multicolumn{2}{|l|}{ Alcohol } & \multicolumn{2}{|l|}{ Cannabis } \\
\hline & & $\begin{array}{l}\text { Adjusted Odds } \\
\text { Ratio* }(95 \% \mathrm{Cl})\end{array}$ & $\begin{array}{l}p- \\
\text { value }\end{array}$ & $\begin{array}{l}\text { Adjusted Odds } \\
\text { Ratio* }(95 \% \mathrm{Cl})\end{array}$ & $\begin{array}{l}\mathrm{p}- \\
\text { value }\end{array}$ & $\begin{array}{l}\text { Adjusted Odds } \\
\text { Ratio* }(95 \% \mathrm{Cl})\end{array}$ & $\begin{array}{l}\mathrm{p}- \\
\text { value }\end{array}$ & $\begin{array}{l}\text { Adjusted Odds } \\
\text { Ratio* }(95 \% \mathrm{Cl})\end{array}$ & $\begin{array}{l}p- \\
\text { value }\end{array}$ & $\begin{array}{l}\text { Adjusted Odds } \\
\text { Ratio* }(95 \% \mathrm{Cl})\end{array}$ & $\begin{array}{l}p- \\
\text { value }\end{array}$ \\
\hline & male only & Ref. & & Ref. & & & & Ref. & & Ref. & \\
\hline \multirow[t]{3}{*}{$\begin{array}{l}\text { Partner during last } \\
\text { anal sex }\end{array}$} & $\begin{array}{l}\text { One non- } \\
\text { steady }\end{array}$ & $1.2(0.9-1.6)$ & 0.257 & $1.5(1.2-1.8)$ & 0.000 & $1.2(0.7-1.9)$ & 0.591 & $1.5(1.3-1.7)$ & 0.000 & $1.1(0.8-1.4)$ & 0.756 \\
\hline & $\begin{array}{l}\text { More than one } \\
\text { partner }\end{array}$ & $3.5(2.2-5.7)$ & 0.000 & $5.6(4.0-7.9)$ & 0.000 & $7.4(3.9-14)$ & 0.000 & $2.4(1.7-3.3)$ & 0.000 & $2.4(1.5-3.8)$ & 0.000 \\
\hline & $\begin{array}{l}\text { One steady } \\
\text { partner }\end{array}$ & Ref. & & Ref. & & Ref. & & Ref. & & Ref. & \\
\hline \multirow{2}{*}{$\begin{array}{l}\text { Having ever } \\
\text { injected drug }\end{array}$} & Yes & $4.8(3.0-7.6)$ & 0.000 & $1.8(1.2-2.7)$ & 0.009 & $5.8(3.1-15)$ & 0.000 & $2.0(1.3-2.9)$ & 0.001 & $2.5(1.5-4.1)$ & 0.000 \\
\hline & No & Ref. & & Ref. & & Ref. & & Ref. & & Ref. & \\
\hline \multirow{2}{*}{$\begin{array}{l}\text { Visiting gay venues } \\
\text { within the last } 3 \\
\text { months }\end{array}$} & $\geq 7$ times & $1.6(1.1-2.2)$ & 0.009 & $1.3(1.1-1.6)$ & 0.005 & - & & $1.7(1.4-2.0)$ & 0.000 & - & \\
\hline & $<7$ times & Ref. & & Ref. & & & & Ref. & & & \\
\hline \multirow{2}{*}{$\begin{array}{l}\text { Satisfaction with } \\
\text { sexual life }\end{array}$} & Very satisfied & - & & $1.2(1.0-1.5)$ & 0.044 & - & & - & & - & \\
\hline & $\begin{array}{l}\text { Not very } \\
\text { satisfied }\end{array}$ & & & Ref. & & & & & & & \\
\hline \multirow{2}{*}{$\begin{array}{l}\text { STI diagnosis, past } \\
12 \text { months }\end{array}$} & Yes & $1.6(1.1-2.4)$ & 0.009 & $1.7(1.3-2.2)$ & 0.000 & $3.0(1.8-5.1)$ & 0.000 & - & & - & \\
\hline & No & Ref. & & Ref. & & Ref. & & & & & \\
\hline city & $\begin{array}{l}\text { (random effect } \\
\text { variance) }\end{array}$ & $0.4(0.1-1.04)$ & & $0.4(0.2-0.9)$ & & $2.1(0.8-5.9)$ & & $0.2(0.1-0.5)$ & & $0.2(0.1-0.7)$ & \\
\hline
\end{tabular}

*multivariable logistic regression with random effect of city. LR test vs logistic $p<0.0001$; "“-" indicates that the variable was not included in the final model for a given dependent variable. 
Figure 1. Party drug, sexual performance enhancement and chemsex drug use before or during last anal sex, by drug class, Sialon II

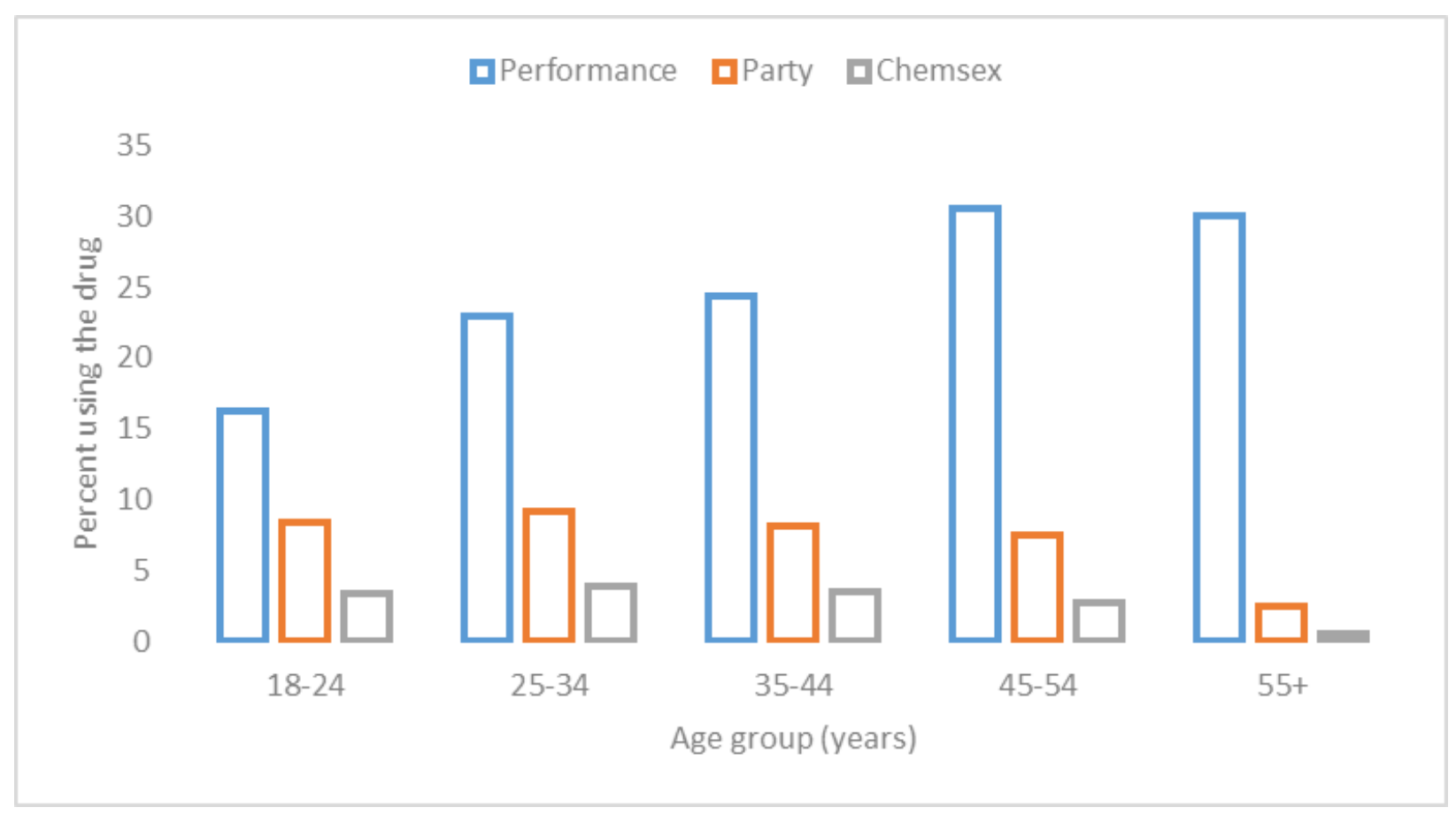


Supplementary Table 1. Intermediate results for the analysis of predictors of use of difference substances: A. Results of univariable logistic regression models; B. Results of random effect logistic regression models (city random effect) with use of different substances as dependant variables, Sialon II

\begin{tabular}{|c|c|c|c|c|c|c|}
\hline \multirow[b]{2}{*}{ Independent variables: } & \multicolumn{6}{|c|}{ Dependant variable: } \\
\hline & Alcohol & Cannabis & $\begin{array}{l}\text { Sexual } \\
\text { performance } \\
\text { drugs (poppers, } \\
\text { EDM }^{* *} \text { ) }\end{array}$ & $\begin{array}{l}\text { Party drugs } \\
\text { (cocaine, } \\
\text { amphetamine, } \\
\text { MDMA) }\end{array}$ & $\begin{array}{l}\text { Chemsex drugs } \\
\text { (GHB, ketamine, } \\
\text { mephedrone) }\end{array}$ & $\begin{array}{l}\text { More than } 1 \\
\text { substance }\end{array}$ \\
\hline \multicolumn{7}{|l|}{ A. Univariable analysis } \\
\hline Age (per year) & $0.98 * * *$ & $0.97 * * *$ & $1.02 * * *$ & $0.98 * *$ & 0.99 & 1.0 \\
\hline Mobile vs native\# & 1.1 & 1.2 & 1.1 & $1.7^{* * *}$ & $2.0 * * *$ & $1.5 * * *$ \\
\hline University education vs. lower & $0.9^{*}$ & $0.5^{* * *}$ & 0.9 & $0.8^{*}$ & $1.7^{* *}$ & 0.8 \\
\hline Out to majority vs. out to less than half & 1.0 & $1.9 * * *$ & $1.4 * * *$ & $1.5 * * *$ & $4.1 * * *$ & $2.2 * * *$ \\
\hline $\begin{array}{l}\text { Neutral positive attitude of work/schoolmates vs } \\
\text { negative }\end{array}$ & 0.7 & 1.2 & $1.2^{*}$ & 1.1 & $1.6^{*}$ & $1.5^{* * *}$ \\
\hline $\begin{array}{l}\text { Neutral positive attitude of parents/family vs } \\
\text { negative }\end{array}$ & 1.0 & $1.3^{*}$ & $1.3^{* *}$ & 0.9 & $1.6^{*}$ & $1.3^{*}$ \\
\hline $\begin{array}{l}\text { Neutral positive attitude of friends vs negative } \\
\text { Self-reported HIV positive vs self-reported }\end{array}$ & 1.0 & 1.0 & 1.2 & 0.9 & $2.8^{*}$ & $1.6^{*}$ \\
\hline $\begin{array}{l}\text { negative } \\
\text { Self-reported HIV indetermined vs self-reported }\end{array}$ & 1.1 & $1.6^{*}$ & $3.0 * * *$ & $2.3^{* * *}$ & $3.1 * * *$ & $3.7^{* * *}$ \\
\hline negative & $0.8^{*}$ & 1.1 & $0.6 * * *$ & 0.8 & $0.3^{* * *}$ & $0.7^{*}$ \\
\hline Having had a female vs only male partners & $1.4^{* * *}$ & $2.5 * * *$ & 1.2 & $2.0 * * *$ & 1.0 & $1.7^{* * *}$ \\
\hline $\begin{array}{l}\text { Last anal sex event - non-steady partner } \\
\text { A. Cont. }\end{array}$ & $1.4 * * *$ & 1.1 & $1.5^{* * *}$ & 1.2 & 1.0 & 1.2 \\
\hline
\end{tabular}




\begin{tabular}{|c|c|c|c|c|c|c|}
\hline \multirow[b]{2}{*}{ Independent variables: } & \multicolumn{6}{|c|}{ Dependant variable: } \\
\hline & Alcohol & Cannabis & $\begin{array}{l}\text { Sexual } \\
\text { performance } \\
\text { drugs (poppers, } \\
\text { EDM }^{* *} \text { ) }\end{array}$ & $\begin{array}{l}\text { Party drugs } \\
\text { (cocaine, } \\
\text { amphetamine, } \\
\text { MDMA) }\end{array}$ & $\begin{array}{l}\text { Chemsex drugs } \\
\text { (GHB, ketamine, } \\
\text { mephedrone) }\end{array}$ & $\begin{array}{l}\text { More than } 1 \\
\text { substance }\end{array}$ \\
\hline Last anal sex event - more than one partner & $2.7 * * *$ & $2.3 * * *$ & $6.2 * * *$ & $3.8 * * *$ & $4.7 * * *$ & $6.5 * * *$ \\
\hline Having ever injected drug & $2.1 * * *$ & $2.9 * * *$ & $2.1 * * *$ & $5.5 * * *$ & $6.8 * * *$ & $4.7 * * *$ \\
\hline \multicolumn{7}{|c|}{ Visiting gay venues last 3 months ( $\geq 7$ times vs $<7$} \\
\hline times) & $1.7^{* * *}$ & $1.4^{* *}$ & $1.6 * * *$ & $2.3 * * *$ & $2.2 * * *$ & $1.9 * * *$ \\
\hline Being very satisfied with sexual life & $0.8^{* *}$ & 1.1 & 1.1 & 1.2 & $1.7^{* *}$ & $1.3 * * *$ \\
\hline STI diagnosis in the past 12 months & $1.4^{* * *}$ & $1.4^{*}$ & $2.1 * * *$ & $2.1 * * *$ & $3.0 * * *$ & $2.3 * * *$ \\
\hline \multicolumn{7}{|c|}{ B. Multiviariable logistic regression models with city random effect } \\
\hline Age (per year) & $0.98 * * *$ & $0.97 * * *$ & $1.02 * * *$ & $0.98 *$ & $0.95^{* * *}$ & 0.99 \\
\hline Mobile vs native\# & $1.48 * * *$ & 1.26 & 1.08 & $1.55^{*}$ & 1.53 & $1.48^{*}$ \\
\hline University education vs. lower & $0.79 * *$ & $0.63 * *$ & $0.78 * *$ & $0.71 *$ & $1.80 *$ & $0.70 *$ \\
\hline $\begin{array}{l}\text { Out to majority vs. out to less than half } \\
\text { Neutral positive attitude of work/schoolmates vs }\end{array}$ & 1.08 & $2.46 * * *$ & 1.13 & $1.85^{* * *}$ & $2.92 * *$ & $2.03 * * *$ \\
\hline negative & 0.86 & 1.01 & 1.00 & 1.10 & 0.89 & 1.16 \\
\hline $\begin{array}{l}\text { Neutral positive attitude of parents/family vs } \\
\text { negative }\end{array}$ & 1.10 & 1.17 & sty.18 & $0.67^{*}$ & 0.78 & 0.86 \\
\hline $\begin{array}{l}\text { Neutral positive attitude of friends vs negative } \\
\text { Self-reported HIV positive vs self-reported }\end{array}$ & 0.94 & 1.17 & 0.70 & 0.86 & 2.79 & 1.22 \\
\hline negative & 1.05 & 1.02 & $2.10 * * *$ & 1.26 & 1.79 & $2.27^{* * *}$ \\
\hline $\begin{array}{l}\text { Self-reported HIV undetermined vs self-reported } \\
\text { negative }\end{array}$ & $1.24 *$ & 1.20 & 0.88 & 0.91 & $0.19 *$ & 0.93 \\
\hline B. Cont. & & & & & & \\
\hline Having had a female vs only male partners & $1.39 * *$ & $3.63^{* * *}$ & $1.37^{*}$ & $2.09 * * *$ & 1.89 & $2.52 * * *$ \\
\hline
\end{tabular}




\begin{tabular}{|c|c|c|c|c|c|c|}
\hline \multirow[b]{2}{*}{ Independent variables: } & \multicolumn{6}{|c|}{ Dependant variable: } \\
\hline & Alcohol & Cannabis & $\begin{array}{l}\text { Sexual } \\
\text { performance } \\
\text { drugs (poppers, } \\
\text { EDM }^{* *} \text { ) }\end{array}$ & $\begin{array}{l}\text { Party drugs } \\
\text { (cocaine, } \\
\text { amphetamine, } \\
\text { MDMA) }\end{array}$ & $\begin{array}{l}\text { Chemsex drugs } \\
\text { (GHB, ketamine, } \\
\text { mephedrone) }\end{array}$ & $\begin{array}{l}\text { More than } 1 \\
\text { substance }\end{array}$ \\
\hline Last anal sex event - non-steady partner & $1.45^{* * *}$ & 1.00 & $1.51 * * *$ & 1.26 & 1.57 & $1.40^{*}$ \\
\hline Last anal sex event - more than one partner & $2.32 * * *$ & $1.94 *$ & $5.46 * * *$ & $3.47 * * *$ & $7.14^{* * *}$ & $6.04 * * *$ \\
\hline Having ever injected drugs & $1.81 * *$ & $2.22 * *$ & $2.03 * *$ & $4.82 * * *$ & $5.73 * * *$ & $4.50 * * *$ \\
\hline $\begin{array}{l}\text { Visiting gay venues last } 3 \text { months ( } \geq 7 \text { times vs }<7 \\
\text { times) }\end{array}$ & $1.69 * * *$ & 1.23 & $1.31 *$ & $1.56 * *$ & 1.24 & 1.32 \\
\hline Being very satisfied with sexual life & 0.87 & 0.95 & $1.25^{*}$ & 1.13 & 1.60 & 1.31 \\
\hline STI diagnosis in the past 12 months & 1.10 & 1.35 & $1.73 * * *$ & $1.62 *$ & $2.20 * *$ & $1.91 * * *$ \\
\hline _cons & 1.17 & $0.07 * * *$ & $0.08 * * *$ & $0.05 * * *$ & $0.00 * * *$ & $0.03 * * *$ \\
\hline city (random effect variance) & $1.25^{*}$ & 1.29 & $1.43^{*}$ & 1.46 & 4.8 & $1.66^{*}$ \\
\hline
\end{tabular}

${ }^{*} \mathrm{p}<0.05 ; * * \mathrm{p}<0.01 ; * * * \mathrm{p}<0.001$

\#Mobile: any situation other than a native living in the country of birth 
Supplementary Figure 1. The most common patterns of substance use during last sexual encounter associated with anal sex, by study site, Sialon II

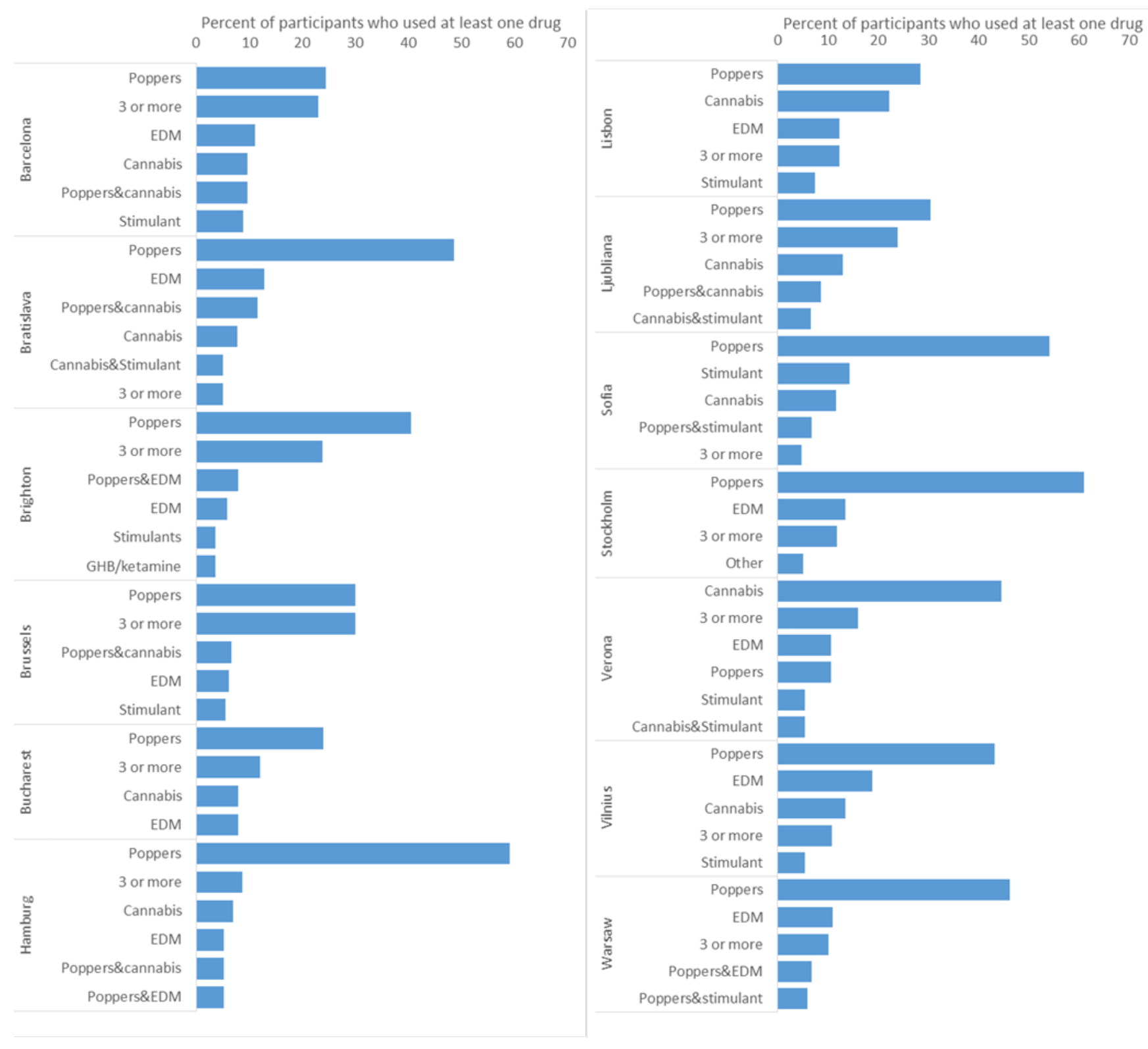

3 or more $=3$ or more substance consumed

EDM $=$ erectile dysfunction medication 